IZA DP No. 7664

Costs and Benefits of Labor Mobility between the EU and the Eastern Partnership Countries:

The Case of Poland

Maciej Duszczyk

Marek Góra

Paweł Kaczmarczyk

October 2013 


\title{
Costs and Benefits of Labor Mobility between the EU and the Eastern Partnership Countries: The Case of Poland
}

\author{
Maciej Duszczyk \\ IPS and CMR, University of Warsaw \\ Marek Góra \\ Warsaw School of Economics and IZA \\ Paweł Kaczmarczyk \\ CMR, University of Warsaw and IZA
}

Discussion Paper No. 7664

October 2013

\author{
IZA \\ P.O. Box 7240 \\ 53072 Bonn \\ Germany \\ Phone: +49-228-3894-0 \\ Fax: +49-228-3894-180 \\ E-mail: iza@iza.org
}

\begin{abstract}
Any opinions expressed here are those of the author(s) and not those of IZA. Research published in this series may include views on policy, but the institute itself takes no institutional policy positions. The IZA research network is committed to the IZA Guiding Principles of Research Integrity.

The Institute for the Study of Labor (IZA) in Bonn is a local and virtual international research center and a place of communication between science, politics and business. IZA is an independent nonprofit organization supported by Deutsche Post Foundation. The center is associated with the University of Bonn and offers a stimulating research environment through its international network, workshops and conferences, data service, project support, research visits and doctoral program. IZA engages in (i) original and internationally competitive research in all fields of labor economics, (ii) development of policy concepts, and (iii) dissemination of research results and concepts to the interested public.
\end{abstract}

IZA Discussion Papers often represent preliminary work and are circulated to encourage discussion. Citation of such a paper should account for its provisional character. A revised version may be available directly from the author. 


\section{ABSTRACT \\ Costs and Benefits of Labor Mobility between the EU and the Eastern Partnership Countries: The Case of Poland ${ }^{*}$}

Poland is a country being exposed to emigration and immigration flows relatively recently. That, among others, results in not fully developed yet institutional infrastructure for managing especially the immigrants flow. In this paper we structure all existing data and other pieces of information on immigrants coming to Poland from the EU Eastern Partnership Countries (EAPs). The vast majority of all types of immigrants from these countries actually originate in Ukraine. On the other hand also a vast majority of them come to Mazowieckie (Warsaw) Voivodeship. The study also confirms Poland is often not a destination country for immigrants. Many of them flow further to the old member states due to the same driver, namely income disparities existing both between EAPs and Poland as well as between Poland and the EU old member states. Nevertheless, the study shows moderate positive impact of immigration fitting demand mostly in agriculture, construction and household services. We analyse an impact of immigration on the domestic labour market in Poland. The immigrants fill gaps existing due to relatively strong and sustained growth contributing to Poland's welfare growth and also due to large scale emigration from Poland to EU old member states. Regulations applying to the immigrants coming to Poland adopted in 20072008 are still in force today. They create institutional infrastructure contributing to increasing scale of employment immigration to Poland. There is no sign the regulations will be substantially changed in the future. We rather expect a step by step development of the currently applied immigration policy.

JEL Classification: F22, J15, J61, J63

Keywords: immigration, impacts of immigration, Eastern Partnership Countries, institutions

Corresponding author:

Marek Góra

Warsaw School of Economics (SGH)

Aleja Niepodleglosci 162

02-554 Warszawa

Poland

E-mail: Marek.Gora@sgh.waw.pl

\footnotetext{
* This discussion paper is a modified and updated version of the paper prepared as a part of the project entitled "Costs and Benefits of Labour Mobility between the EU and the Eastern Partner Partnership Countries" for the European Commission (Contract No. 2011/270-312, tender procedure EuropeAid/130215/C/SER/Multi), see IZA Research Report No. 56.
} 


\section{Contents}

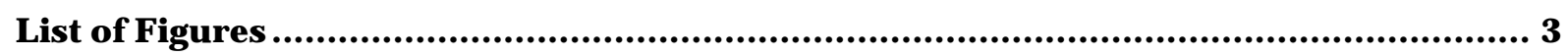

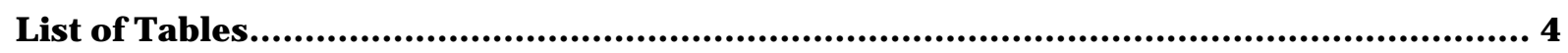

List of Acronyms

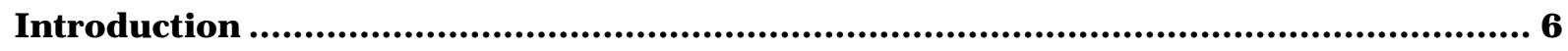

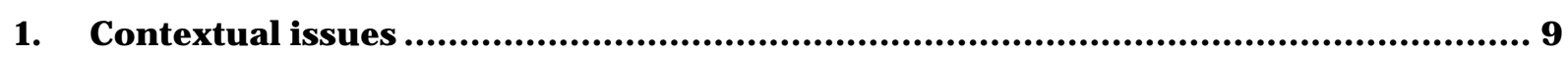

2. Legal framework for inflow of migrants from the EAPs to Poland...............................10

2.1. General rules concerning employment of foreigners ……………………………………. 10

2.2. Undertaking of employment in Poland by foreign nationals without obligation to hold a work

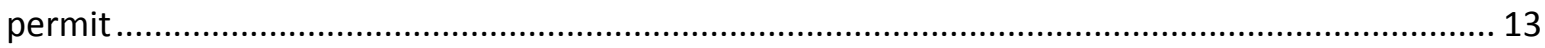

3. Stocks of EAPs migrants and their structural features ................................................... 16

3.1. Immigration to Poland - a general picture …………………………………………... 16

3.2. Flows and stocks of EAPs immigrants ............................................................................... 17

3.3. Employment of foreign workers - scale of labor migration ................................................... 17

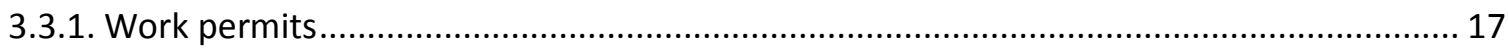

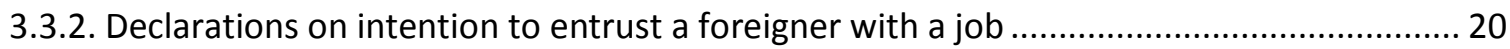

3.3.3. Foreigners' employment in view of the data from the Social Insurance Institution .......... 24

3.3.4. Sectoral structure of foreigners' employment............................................................... 25

3.4. Legal employment of EAPs immigrants in Poland.................................................................. 26

3.4.1. Structural characteristics of Ukrainian migrants in Poland .................................................. 29

3.4.2. Persons who were admitted on the basis of simplified procedure (declarations) .............. 32

4. Costs and benefits of the EAPs immigration ................................................................. 36

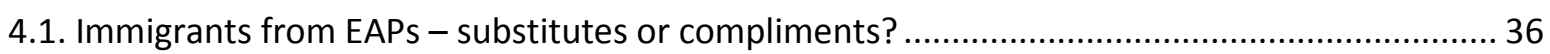

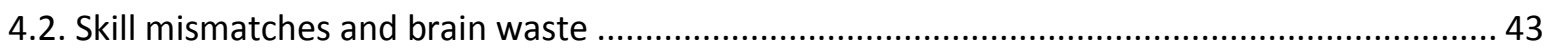

4.3. General assessment of the labor market integration of the EAPs immigrants......................... 46

4.4. Impact of the EAPs immigration on the welfare system ............................................... 50

5. Prospects for future inflow from EAPs .......................................................................55

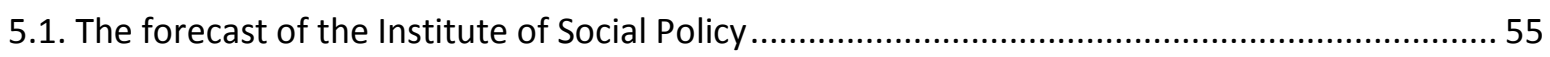

5.2. The forecast of the Centre of Migration Research .......................................................... 56

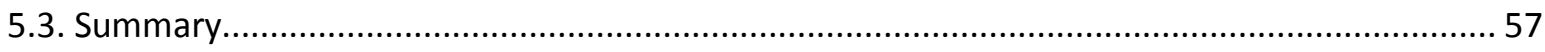

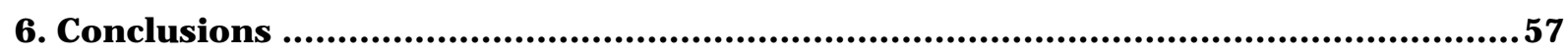

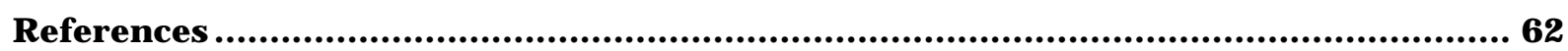




\section{List of Figures}

Figure 1.1. Real GDP growth - Poland, EU15 and EU27, 1999-2012

Figure 3.1. Number of applications and issued work permits in the years 2004-2012 (including those for citizens of the member states of the EU, the EEA and of Switzerland) 18

Figure 3.2. Number of declarations issued

Figure 3.3. Year-to-year changes (in \%) in the number of declarations, by nationality (2008-2011) 23

Figure 3.4. Seasonal pattern of the registered declarations, 2011. 24

Figure 3.5. Structure of employment according to work permits, 2011 ........................27

Figure 3.6. Immigrants from Ukraine in Warsaw by purpose of stay. 31

Figure 3.7. Structure of employment of Ukrainian immigrants in Warsaw area (RDS sample 2010)

Figure 4.1. Real and potential demand by firm size .37

Figure 4.2. Real and potential demand by firm size and sector .................................. 38

Figure 4.3. Real demand by firm size and country of origin 39

Figure 4.4. Shares of firms employing foreigners in specific occupations, by firm size and type of demand (actual and planned).......................................................... 40

Figure 4.5. Rationale for employing foreigners, by firm size ..................................41

Figure 4.6. The character of jobs performed by foreigners, by firm size ...................... 42

Figure 4.7. Sectors of employment of EAPs immigrants in Warsaw area (RDS sample 2010), percentages.

Figure 4.8. Net fiscal position of Ukrainian migrants in Poland, by age groups, in PLN (annually) 


\section{List of Tables}

Table 3.1. Work permits issued to nationals of the member states of the Eastern Partnership.

Table 3.2. The number of work permits issued to foreigners posted to Poland for provision of services in the years 2004-2011

Table 3.3. The number of declarations on intention to entrust a foreigner with a job, by nationality of worker, 2007-2012.

Table 3.4. The most numerous nationalities among foreigners coming from third countries registered for old-age pension insurance - as of 31st December 2012 .

Table 3.5. Sectors of employment according to work permits issued, EAPs, 2011

Table 3.6. Structure of employment according to work permits issued, EAPs, 2011...... 28

Table 3.7. The main socio-demographic characteristics of immigrants and Polish citizens, 2010 and 2012 .

Table 3.8. Structural characteristics of Ukrainian seasonal workers, 2007-2011

Table 3.9. Structural characteristics of Belorussian seasonal workers, 2007-2011 ....... 33

Table 3.10. Structural characteristics of Moldavian seasonal workers, 2009-2011........ 34

Table 3.11. Structural characteristics of Georgian seasonal workers, 2010-2011.......... 34

Table 4.1. Level of education of the EAPs immigrants in Warsaw area

Table 4.2. EAPs immigrants in Warsaw area by sector of employment and education (RDS sample), in percentages.

Table 4.3. Number of unemployed and inflow (number of people registered in 1 st half of 2011 - J une 2011) by 1-digit groups of professions . .47

Table 4.4. Basic data on the Polish labor market and the number of legally working immigrants 49

Table 4.5. Net fiscal position of Ukrainian immigrants in Poland - scenarios 53 


\section{List of Acronyms}

CMR - Centre of Migration Research

CSO - Central Statistical Office

EAPs - Eastern Partnership Countries

EEA - European Economic Area

EU - European Union

EU-15 - "old" members of the EU

FDI - Foreign Direct Investments

GDP - Gross Domestic Product

LFS - Labour Force Survey

MLSP - Ministry of Labour and Social Policy

PKD - Polish Classification of Activities

RDS - Respondent Driven Sampling

TFR - Total Fertility Rate 


\section{Introduction}

Immigration to Poland is a relatively new phenomenon. ${ }^{1}$ Moreover, even now, when migrants can relatively easy enter Poland and start a job (regular or in the shadow economy) its scale is still limited, particularly as compared to the Western European countries struggling with massive inflows of foreigners. Thus, problems of a country receiving immigrants are known mostly from observation of situation in other countries.

However, the situation in Poland is changing. The scale of immigration, not being large, has become noticeable. It is likely the scale will increase in the future as a result of attractiveness of the EU in general as well as of opportunities created by the Polish economy. That creates challenges for the country in general and for social and labor market institutions in particular. A special role in the story play immigrants from the Eastern Partnership Countries (EAPs) which in fact constitute the main group of newcomers.

As compared to immigration to Poland, the scale of emigration from Poland is much larger ${ }^{2}$. Being an emigration country is a role Poland has played for more than 100 years. Recently that process became significant after the accession to the European Union in 2004. Many Poles have emigrated temporally or for longer period (whereas 'permanently' seems not to be a proper expression here-people simple do not know when and whether they will come back at all). Public perception is focused on emigration not on immigration. The latter is becoming permanently present in the public debate, however, not being in its very center, as the emigration is, particularly since the EU enlargement.

The presence of immigrants requires institutions. They have to regulate entire social and economic life of the immigrants. However, in order to regulate we need to know what the real situation is in various areas such as education, health services and obviously labor market. The latter is particularly difficult for analysis since the migrants may tend to work in entirely or partially shadow market. That leads to many negative outcomes and also causes we do not have appropriate data needed for an

\footnotetext{
${ }^{1}$ New in times present in people's memory. Relatively large inflows of immigrants entered Poland in $16^{\text {th }}-18^{\text {th }}$ century.

${ }^{2}$ However, it is important to note that figures on both immigration and emigration are to a large extent fuzzy (even if reasons for that may differ in case of outflow and inflow).
} 
analysis of situation and designing policies. In such case it is a good practice to assume Poland being different from other countries is at the same time similar. Moreover, the similarities are most probably stronger than differences. Consequently, in some case it is possible to draw conclusions needed for designing policies towards immigrants based on international comparisons.

The goal of our study is different. We have tried to put together and analyze data and other pieces of information available in Poland with respect to immigration from the EAPs. The analysis we present is based on empirical studies and aims at developing the best possible picture of the case of immigration to Poland, with special emphasis on inflow from Ukraine being the most important single origin country of persons incoming to Poland.

The analysis of immigration from Eastern Partnership countries to Poland is central from the viewpoint of creation of recommendations for Polish immigration policy and, more broadly, of demonstrating the specifics of Poland as a member states of the European Union, and consequently of expanding the picture of immigration into the Community. Particularly important in this context is to answer the question about the role of employment immigration from Eastern Partnership countries for Polish labour market and the demand on the part of Polish employers for hiring foreigner. The main added value of this study is to demonstrate the impact of liberalisation of regulations governing employment immigration on the scale and directions of foreigners' inflow into the labour market. The reference publications so far have failed to present an exhaustive analysis showing the changes in the inflow of foreigners into Poland after 2007, when liberalization of immigration regulations started, and answering the questions about the sectors and regions of foreigners' employment. Focusing on employment immigration from Eastern partnership countries ensued from the research hypothesis assuming that citizens of those countries will be the main beneficiaries of the changes in immigration regulations.

Summarising, the fundamental changes regarding immigration regulations, which liberalised the rules governing inflow of foreigners from third countries into Polish labour market initiated in 2006, were caused by emigration of Poles into other EU member states on the one hand and by relatively good situation of Polish labour market on the other. Another important factor was comprised by the pressure from employers (particularly in farming and construction sectors), who at that time voiced demand for employees, which could not be satisfied by domestic labour force. Particularly important for immigrants' inflow were two solutions: introduction of a simplified labour market test procedure, which facilitated the possibility to obtain a permit to employ foreigners, and introduction of a new instrument of employer's declaration of the intention to entrust employment to a foreigner without the obligation to obtain a permit. In practice the latter solution opened Polish labour to seasonal employment from four countries of Eastern Partnership and Russia. Only with minor correction, the solutions adopted in the period 2007-2008 are still in force today and, as demonstrated by statistical data presented in this paper, 
fundamentally contributed to enlargement of the scale of employment immigration to Poland.

The structure of the study is a follows. We start with a short introductory chapter showing recent developments in terms of economy and demography. These kinds of factors seem to influence significantly patterns of immigration as well as absorbing capacities of Polish labor market. Chapter 2 looks at institutional rules concerning inflow from the EAPs, with particular emphasis on newly established simplified procedures. The aim of chapter 3 is to assess in statistical terms both flows as well as stocks of EAPs immigrants in Poland. All possible data sources have been used in order to get relatively appropriate picture of the process. Chapter 4 looks at impacts of recent inflow from the EAPs with particular emphasis on the labor market related issues. Finally, concluding part includes short discussion on future trends in migration under analysis. 


\section{Contextual issues}

Poland's accession into the EU influenced many areas of life and seriously shaped recent economic situation of the country. Between 2005 and 2008 Poland experienced rapid economic growth marked by over 5\% annual GDP growth rate accompanied by significant inflow of Foreign Direct Investment (with accumulated stock of FDI as high as $40 \%$ of GDP in 2009). In terms of labor market measures, post-accession period meant an increase in employment rates and decrease in number of unemployed and serious improvement in labor market situation, particularly as compared to pre-2004 period. Although, the growth become weaker after 2009 it was relatively strong as compared to the rest of Europe (see Figure 1.1).

\section{Figure 1.1. Real GDP growth - Poland, EU15 and EU27, 1999-2012}

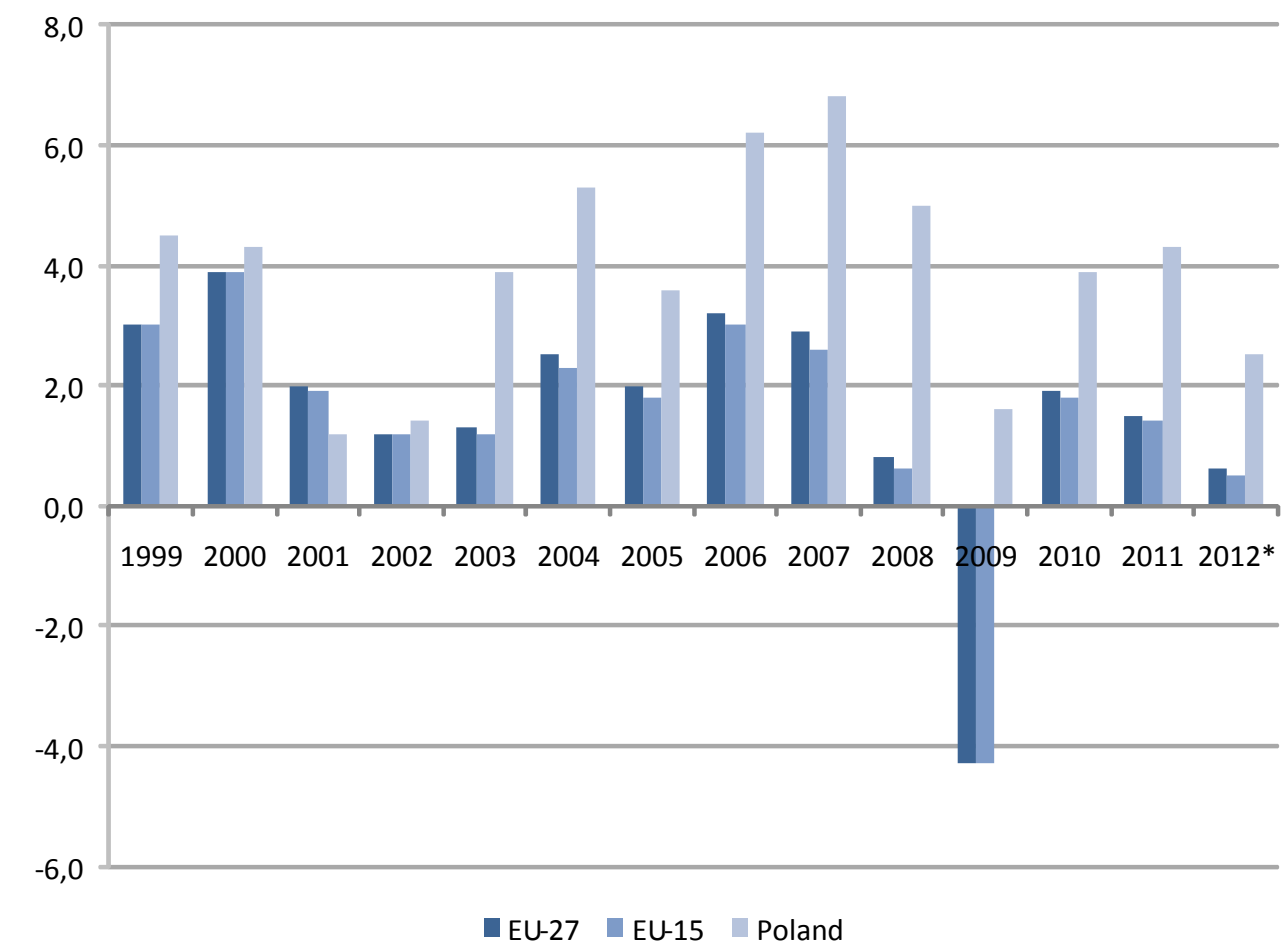

Source: Own elaboration based on Eurostat data.

In the context of this report it is necessary to evaluate 1) demographic developments and 2) situation on the labor market ${ }^{3}$ :

In demographic terms Polish society belongs to the youngest in the whole EU which is to be linked to baby boom of 1950s and its echo recorded in 1970s. However, this situation is changing on much faster pace than observed before in the western European countries along with the dynamics of Second Demographic Transition observed in Poland. Total Fertility Rate (TFR) decreased from over 2.4 in 1983 to 1.2

${ }^{3}$ Based on Fihel et al. 2012. 
in 2003 (similarly to other post-socialist countries) and then raised only moderately (to over 1.4). On the other hand, life expectancy is on constant rise: since 1989 the life expectancy at birth increased by over 5 years for men (to 71.5 years in 2009) and 4.9 years for women (to 80.1 years). This process is to be perceived as one of major achievements of Poland in last 20 years, however, when juxtaposed to dramatically low fertility rates it leads to serious changes in the age structure of the population. Ageing of the Polish population is expected to influence both labor market phenomena as well as the welfare since 2020 onwards and may - for obvious reasons - impact immigration to Poland (e.g. growing demand in personal services).

One of the main issues which seriously impacted general perception of Poland as country of destination was the situation on the labor market. As shown on the figure below Polish economy for almost whole period of transition was marked by very high unemployment rate reaching $20 \%$ in 2002. It needs to be stressed, however, that from 2005 to 2008 the level of unemployment declined, reaching the EU average level in 2009. As of the end of 2012, the unemployment rate in Poland (according to Eurostat data) reached 10.6 per cent against EU-27 average of 10.8 per cent.

Thus it is important to acknowledge that one of the main outcomes of the postenlargement economic boom was serious improvement of the situation on the labor market. This trend was particularly well visible until 2007 when unemployment rate (according to the LFS) felt below $10 \%$. At the same time employment rates started to increase and this was the very first time since early 1990s when Poland experienced significant drop in economic inactivity (caused mainly by the structural change in public sector). In 2011 employment rate in Poland was as high as 59.7, still far below the EU average but significantly higher than in the pre-accession period (e.g. merely $51 \%$ in 2002-2004). Economic downturn brought an end to the process of mass job creation and impacted negatively unemployment rates.

\section{Legal framework for inflow of migrants from the EAPs to Poland}

\subsection{General rules concerning employment of foreigners}

The making of Polish immigration-related legislation in the post-1989 period was stimulated predominantly by fears of massive and uncontrollable influx of the citizens of Eastern states, who were supposed to escape their respective countries owing to expected destabilization and economic downturn after the fall of the Soviet Union (Aniol 1995). Such an approach clearly favored the priority of security, while the issue of the employability of foreign nationals and of drawing labor market benefits there from failed to be addressed in the debate about future Polish immigration policy in the just emerging Third Republic of Poland. Additionally, situation on the Polish labor market marked by severe (and raising) levels of unemployment could be commonly used by policy makers not interested in intensification of migration streams. Simultaneously, still in 1989 a decision was made to address the issue of the employment of foreign country nationals jointly with 
the matters of employment emigration of Poles under the act regulating the issues of labor market policy and combating unemployment ${ }^{4}$.

A fundamental amendment to the legal provisions concerning employment of foreign country nationals was carried into effect upon Poland's accession to the European Union ${ }^{5}$. Further changes were made in the years that followed. As an example, farreaching simplification was performed on the legislation concerning work permits for foreign nationals ${ }^{6}$. This covered, e.g. elimination of prior extremely bureaucratized procedures regarding work permits, liberalization of the procedure for the performance of the so-called labor market test, and extension to three years of the maximum period for which the work permits are issued.

One of major events in the immigration policy-making in the part concerning taking of employment by foreign nationals in Poland was comprised by adoption in 2006 of a catalogue of groups released from work permit-holding obligation?. This rule was further modified (and extended) in $2011^{8}$.

An analysis of the legislation concerning employment of foreign nationals in Poland demonstrates that it divided foreigners into two main categories:

- citizens of the member states of the European Union, including also citizens of Norway, Iceland, Lichtenstein and Switzerland, who may take employment in Poland without a permit owing to their citizenship,

- citizens of third countries who - as a rule - are obliged to hold a work permit.

In the former case Polish legislation follows directly from free movement of workers. As a member country of the European Union, Poland is obliged both to implement the acquis and adjust its legislation accordingly to judgments of the European Court of Justice.

In the latter case the procedure looks in a following way. According to the work permit issuing procedure, a party thereto is a potential employer, who needs to place a job offer for a given position in a Poviat Employment Agency. A work permit is issued by a voivode ${ }^{9}$ at employer's request.

\footnotetext{
${ }^{4}$ Chapter 6 of the Act on employment of 29th December 1989 (the J ournal of Laws of 1989 No. 75 items 445 and 446).

5 The Act on employment promotion and labour market institutions of 20th April 2004 (the J ournal of Laws 2004 No. 99 item 1001).

6 The amendment to the Act on employment promotion and labour market institutions of 19th December 2008 (the J ournal of Laws 2009 No. 6 item 33).

7 The Regulation of the Minister of Labour and Social Policy on performance of work by foreigners without a necessity to obtain a work permit (the J ournal of Laws 2006 No. 156, item 1116).

8 The Regulation of the Minister of Labour and Social Policy on the cases in which the assignment of work for a foreigner in the territory of the Republic of Poland shall be permitted without obtaining a work permit of 20th J uly 2011 (J ournal of Laws No. 155, item. 919).

9 Official representative of the government at the regional level in Poland (head of the regional government).
} 
Before issuing a work permit, a two-part labor market test is performed. Firstly, the salary offered to a foreign national is examined; this cannot be lower than remuneration for domestic employees performing comparable work or discharging a comparable function. This aims to prevent salary dumping from foreign nationals. Secondly, it is examined whether employment of a given foreign national is not to cause negative impacts on the local labor market, particularly whether it might negatively influence job-seeking opportunities of people registered in a given poviat employment agency. To this end, it is examined whether it is possible to satisfy employer's needs from the register of the unemployed and job-seekers. If such register does not contain a proper candidate but it is likely that such people can be found at a given local market, an additional recruitment for the vacancy notified by an employer is announced. The test-performing body (a starost) informs the permitissuing body (a voivode) about the performed labor market test within 7 days. However, if additional recruitment of domestic employees has been performed, this period amounts to 14 days.

The labor market test does not have to be performed if a voivode decides to propose a list (which has to be published in the voivodeship journal of laws) of deficitjobs and types of occupations in the work permit issuing, and a given employer notifies demand for an employee with exactly such skills. The labor market test is also not performed when a voivode issues extension of work permit for the same foreign national and in the same position, or if such solution follows from other regulations (e.g. the work permit is issued for a given foreign national without labor market test if she/ he was employed for at least three months pursuant to a declaration with the same employer who applies for a permit).

Separate legislation governs positions of the members of management boards and posted workers. In their case, however, no labor market test is performed.

Simultaneously, remuneration of posted workers is examined for possible dumping. It may not be lower by more than $30 \%$ compared to an average monthly salary in a given voivodeship, as announced by the Central Statistical Office.

Preferences in the access to Polish labor market through application of simplified procedure in the issuing of work permits were also applied to the foreign nationals who either in the period of 3 years preceding filing of the work permit application graduated from a school or high school having its registered seat in the territory of the Republic of Poland or another member states of the European Economic Area or the Swiss Confederation, or in the period of 3 years preceding filing of the work permit application resided lawfully in the territory of the Republic of Poland, and their stay was uninterrupted according to the meaning of the aliens act.

An analysis of the work permit issuing rules adopted in Poland demonstrates that they can be reckoned as liberal and not excessively bureaucratic ones. The labor market test performance obligation aims to prevent any obvious cases of substitute employment of foreigners in relation to Polish nationals or other foreign nationals 
who are allowed to take permit-free employment in Poland. This obligation is well understandable when considering situation on the Polish labor market which started to improve only in the post-2004 period. Imposition on starosts of the obligation to report the information about labor market test results within 7 or 14 days seems fully justified. A certain problem may be posed by reliability of the registers held by poviat employment agencies, but the period of 14 days shall allow for performance of additional recruitment by officials, who should have adequate recognition of the local labor market from the perspective of employee deficits and surpluses. Further, the labor market test rules should not impose limitations on employers. The waiting period for the labor market test results, and then for work permit shall not adversely affect the recruitment plans and delay taking of a given job by a foreign national.

The period for which work permits are issued seems well taken too. The maximum period of three years on the one hand provides employment stability to both an employee and employer, while on the other a given foreign national does not acquire the right of permanent residence already with the first work permit.

\subsection{Undertaking of employment in Poland by foreign nationals without obligation to hold a work permit}

In the context of this report it is important to note, that Poland is among the countries which in recent years seem to have taken a different route than a majority of other member states of the European Union or OECD countries. Poland has decided to liberalize gradually the legislation on employment of third country nationals, which is manifested in facilitation of work permit-issuing regulations on the one hand, and in the extension of the catalogue of foreigners' groups allowed to take employment in Poland without the necessity to hold a permit, under certain conditions though, on the other. Importantly, these changes targeted at least a few out of the EAPs.

One of the categories of foreign nationals who do not have to obtain work permit in Poland are citizens of the Republic of Belarus, the Republic of Georgia, the Republic of Moldova, the Russian Federation, and Ukraine, performing work for a period not exceeding 6 months within consecutive 12 months pursuant to employer's declaration. It can be assumed that in their case Poland decided to introduce facilitations as an element of conscious immigration policy from the perspective of present and future labor market needs. It must be assumed that elimination of the work permit holding obligation resulted from labor market situation in their case. In the case of East European citizens the aim was to replenish shortages in laborintensive sectors, where Polish nationals willing to take such employment are missing. This concerns mainly temporary employment, i.e. only temporary replenishment of shortages in particular local labor markets ${ }^{10}$.

\footnotetext{
${ }^{10}$ It is necessary to note, however, that the introduction of new regulations concerning so-called seasonal workers were driven purely by pragmatic needs of supporters of one coalition party (i.e. farmers) and the whole legislation process differed significantly from typically observed ones.
} 
The procedure is following: an employer wishing to offer temporary seasonal employment to citizens from the said five East European countries is obliged to submit relevant declaration to the poviat employment agency. The declaration form can be obtained directly from any poviat employment agency or printed after downloading from any of several websites.

Completion of the data required in the declaration form must be assessed as a straightforward process, not likely to be problematic for anyone knowing who they want to invite and what type of employment they want to entrust to such person. It is required to supply the period and place where employment will be performed as well as the type of contract governing such employment, plus the amount of envisaged gross salary. Additionally the declaration shall include the basic personal data of a given third country national required for visa issuing: i.e. full name, birth date, passport number, plus the locality, district and state of permanent residence.

The employer submitting the declaration has also to become acquainted with the legislation concerning residence and employment of foreign nationals in Poland and ascertain that its staffing needs cannot be satisfied on the basis of the local labor market. In both cases both the knowledge and the undertaken actions in the field of search for employees are not to be verified and do not require any certificates.

Registration of the declaration in the poviat employment agency does not entail any costs. After registration the declaration has to be supplied to the person onto which it was issued. This can be done directly if the person concerned is in Poland, e.g. on a tourist stay and wants to apply for a visa in the country of origin, or by mail.

It is up to the employee onto whom the declaration was issued to obtain a visa with work permit. To obtain one it is necessary to meet a procedure stipulated by law. The duration of the procedure depends on both the employee's country of origin and efficiency of a given consular office. In the case of citizens of Ukraine, Belarus, Russia, Moldova and Georgia, the period between filing the application and getting the visa may vary from 7 to 20 days. Anyway this period shall be deemed as unproblematic one as concerns undertaking of employment. The very registration in the consulate is usually made via Internet, which greatly accelerates the procedure.

The complete procedure from registration of the declaration in a poviat employment agency, through its delivery to a potential employee, to getting a visa and coming to Poland shall take not more than 14-30 days.

Elimination of the obligation to issue work permits to temporary employees from the said five East European countries was an interesting solution, particularly concerning emigration-immigration situation of Poland and the general stance towards inflow of foreigners. Interestingly (see section 3.3) this ad-hoc measure turned out to be one of the most important 'gates' towards Polish labor market and its importance is growing even in time of economic downturn. Simultaneously, introduction of several additional facilitations should be considered. As an example, it should be considered 
whether now, as the system has been sealed against abuses, the maximum employment period could be extended up to 9 months within 12 successive months. Also a procedure could be introduced to cover with this instrument the citizens of other states, also non-East European ones. It would be also possible to introduce a solution whereby a foreign national hired three times pursuant to a declaration (the combined employment time would need to total at least 12 months) would acquire the right of free access to Polish labor market, provided he did not breach Polish law as regards employment lawfulness in the period of prior employment. 


\section{Stocks of EAPs migrants and their structural features}

\subsection{Immigration to Poland - a general picture}

Poland is an emigration country. The entry to the country was seriously blocked for a few decades following the end of the Second World War, since then emigration from Poland has been far more important (in numerous terms) than inflow to the country. This kind of picture is clear when analyzing official register data on emigration and immigration.

Generally, between 2001 and 2012 as many as 130 thousand persons registered in Poland for permanent stay and in the same period the number of emigrants accounted to 290 thousand. However, there are several methodological problems with the above presented data. Firstly, it refers only to those persons who arrived to Poland with an intention to settle (permanent stay) and registered with local administration. Secondly, presented data includes information on both Polish nationals as well as foreign nationals, thus it is impossible to distinguish between 'real' immigration and return migration (see also Fihel et al. 2012).

Much better estimate concerning foreigners residing in Poland is provided by the Central Statistical Office (on the basis of the Labor Force Survey). According to this estimate the number of foreigners (aged 15 and more) varied between 39 thousand ( $3^{\text {rd }}$ quarter) and 50 thousand (I quarter) in 2010 and equaled 44 thousand in the $1^{\text {st }}$ quarter of 2011 and 41 thousand in the $2^{\text {nd }}$ quarter of 2011. The number of foreign nationals among persons who arrived from abroad and registered for a temporary stay of above 3 moths (including both Polish as well as foreign nationals) equaled in 200953.5 thousand with Ukraine, Belarus and Germany ${ }^{11}$ of as the most important sending countries .

According to the figures from the Office for Foreigners as of 31st December 2012 around 100 thousand foreign nationals held valid residence cards. The largest number of residence cards (29 per cent) was issued to Ukrainian nationals.

Last but not least, recently published results of the National Population and Housing Census held from 1st April to 30th J une 2011 are worth noting (mostly due to the fact that it was the first one since Poland's accession to the European Union) ${ }^{12}$. Census data revealed that among permanent residents of Poland almost 99.8 per cent are citizens of the Republic of Poland and only 0.15 per cent $(57,500)$ are foreigners including 55,400 non-Polish nationals (against 40,200 in 2002), and approx. 2,000 who defined themselves as stateless persons. 98.1 per cent of the population living in Poland named Poland as the country of their birth ${ }^{13}$. Ukrainians were the largest

\footnotetext{
${ }^{11}$ In case of Germany a significant of inflowing migrants represent persons of Polish descent.

12 The census was performed in buildings, apartments, collective accommodation facilities and other inhabited non-housing premises. It covered people permanently residing (registered) in the territory of Poland regardless whether those people were in the country during the census or stayed abroad plus people staying temporarily. ${ }^{13}$ In case of Poland there is a serious problem with statistics referring to country of birth - at the beginning of 2011 the number of persons stating country of birth different than Poland was as high as 270 thousand but this
} 
group among foreigners residing in Poland (24.1 thousand), followed by Germans (9.2 thousand), then by Belarusians ( 7.5 thousand) and Russians ( 7.2 thousand). Almost one in three foreigners was staying in Mazowieckie voivodeship, followed by Dolnośląskie and Małopolskie voivodeships.

\subsection{Flows and stocks of EAPs immigrants}

As clearly shown in the previous section, Poland is still a net emigration country, however, there are some premises suggesting gradual change in its status towards being emigration-immigration country.

Ukraine is definitely the most important origin country of temporary immigrants coming to Poland - the number of such immigrants has been increasing. The next important country constituted Belarus followed by Armenia and Moldova. Numbers of migrants originating from Azerbaijan and Georgia were extremely low during the last years.

Obviously, the scale of passenger cross-border traffic is much higher than any kind of migration measure. The number of arriving Ukrainians and Belarusians is changing along with the changes in business cycle but the scale of this flows is very high - in case of Ukraine it varied between 3.3 and 5.6 million arrivals annually (between 5.5\% and $8.7 \%$ of the total number of arrivals). It may suggest relatively high international mobility between two neighboring countries whereas only part of it could be measured officially. The case of seasonal workers and spectacular success of the socalled simplified procedure (see below) may serve as a supportive argument in favor of this thesis.

\subsection{Employment of foreign workers - scale of labor migration}

Any analysis of the scale of foreigners' employment in Poland is highly risky owing mainly to ineffective monitoring system and unknown scale and structure of grey zone employment. The major data sources to draw conclusions upon are the statistics kept by the Ministry of Labor and Social Policy concerning work permits and declarations registered in poviat employment agencies of the intention to entrust employment to foreigners. Unfortunately frequent legislative amendments concerning the permits and declarations, as well as difficulties in the analysis of the employment of foreigners without permit-holding obligation, all adversely influence any analysis being performed, particularly in a longer-time perspective.

\subsubsection{Work permits}

Work permits are the major instrument applied by states receiving immigrants as regards regulations of foreigners' access to their labor markets (see section 2.1). In the period following Poland's accession to the European Union, Poland decided to liberalize greatly the legislation concerning issuing of work permits and to expand the

was mainly due to changes in state borders in the post-war period and the fact that in case of many citizens of Poland born prior to 1939 their place of birth ceased to be part of Polish territory (Fihel et al. 2012). 
groups which are not required to hold such permits ${ }^{14}$. This leads to a conclusion that Poland is interested in having foreigners taking employment and replenishing labor market shortages flowing hereto.

Figure 3.1. Number of applications and issued work permits in the years 2004-2012 (including those for citizens of the member states of the EU, the EEA and of Switzerland)

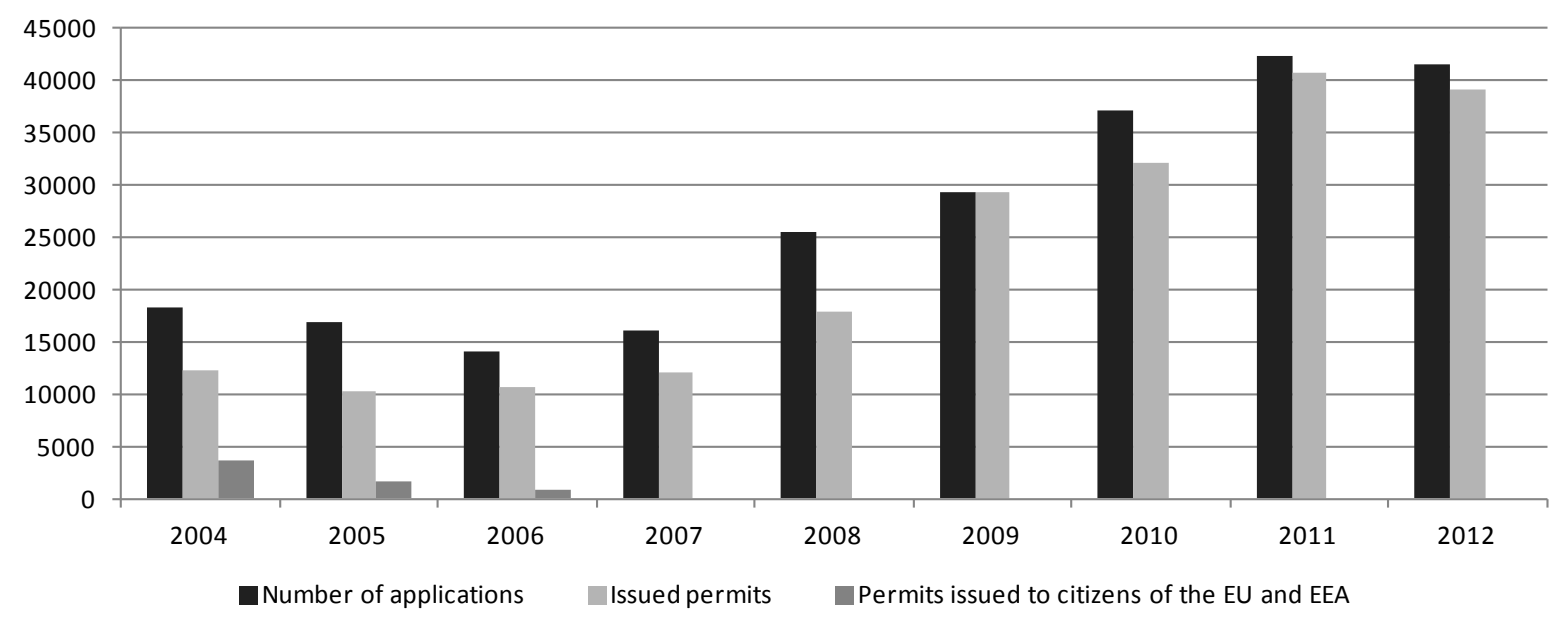

Source: Own elaboration based on the data from the Ministry of Labor and Social Policy (data on temporary employment of foreigners).

Based on the analysis of data concerning work permits it can be ascertained that the scale of foreigners' inflow into Poland is growing. A dynamic growth in the number of work permits was recorded in the years 2007-2012. In 2004, when Poland acceded to the European Union, 12,381 permits were issued, and in 2007 the number of issued permits was at a similar level, amounting to 12,153. In 2011 the number went up to 40,808 permits. In 2012 the number of issued permits dropped to 39144.

It has to be pointed out, however, that owing to the phenomenon of unregistered work, the values concerning lawful employment are the lower limit of the range where actual size of immigrant stream is to be found. Moreover in connection with Poland's accession to the European Union and elimination of work permits for citizens of the European Union states, the data from mid-2006 onwards ${ }^{15}$ are complete and reliable only for third country nationals and therefore only for them the emerging trends can be directly followed. However in the case of the analysis referring mainly to citizens of the Eastern Partnership states, this is hardly of any relevance.

\footnotetext{
14 The amendment to the Act on employment promotion and labour market institutions, which entered into force on 1st February 2009, and introduction in 2007 of the system of declarations on intention to entrust a foreign national with a job without necessity to apply for a work permit.

${ }^{15}$ In the case of Ireland, Sweden and the United Kingdom this happened already on 1st May 2004; nevertheless those countries are relatively not significant sources of immigration to Poland.
} 
This also means that when performing a general analysis of the trends in place, it should be assumed that in the years 2006-2007, owing to elimination from the statistics of the citizens of EU member states and of Norway, Iceland, Lichtenstein and Switzerland, the growth in the number of employment immigrants was greater than absolute numbers would suggest.

According to the data on work permits in Poland, a decisive majority thereof (approx. $85 \%$ in 2004, over $90 \%$ in 2011) is attributable to European non-EU states (the states of the Eastern Partnership, the Balkan states) and Asia (mainly China and SouthEastern Asia), with the share of Asia regularly growing, mostly at the expense of North America. Compared to Europe and Asia, in quantitative terms the role of immigration from Americas, Africa and Australia is small.

Nationals of the states comprising the Eastern Partnership are, and will most likely be in the future, an important category of employment immigrants. Poland is definitely the greatest advocate of this covenant and aims at its dissemination, and at liberalization of the movement of persons between those states and the European Union. An analysis of the work permits issued to citizens of those states clearly suggests that their number is growing dynamically. In 2012 they were issued with 22,363 work permits, corresponding to almost 60 per cent of all issued permits (see Table 3.1).

Table 3.1. Work permits issued to nationals of the member states of the Eastern Partnership

\begin{tabular}{|c|c|c|c|c|c|c|}
\hline \multirow[t]{2}{*}{ Year } & \multicolumn{6}{|l|}{ Country } \\
\hline & Ukraine & Belarus & Moldova & Georgia & Azerbaijan & Armenia \\
\hline 2007 & 3,851 & 855 & 971 & 62 & 21 & 304 \\
\hline 2008 & 5,400 & 1,325 & 1,218 & 109 & 19 & 441 \\
\hline 2009 & 9,504 & 1,669 & 601 & 143 & 37 & 619 \\
\hline 2010 & 13,150 & 1,958 & 682 & 95 & 45 & 452 \\
\hline 2011 & 18,523 & 1,385 & 1,042 & 173 & 53 & 465 \\
\hline 2012 & 19,357 & 1,723 & 609 & 171 & 70 & 433 \\
\hline
\end{tabular}

Source: Own elaboration based on the data from the Ministry of Labor and Social Policy.

The states of the Eastern Partnership are also leading the statistics of the number of permits issued to posted workers. 
Table 3.2. The number of work permits issued to foreigners posted to Poland for provision of services in the years 2004-2011

\begin{tabular}{|l|l|l|}
\hline Year & $\begin{array}{l}\text { Number of } \\
\text { permits }\end{array}$ & $\begin{array}{l}\text { Including the greatest number } \\
\text { issued to nationals of (numbers in } \\
\text { parentheses): }\end{array}$ \\
\hline 2004 & 798 & Ukraine (155) \\
\hline 2005 & 847 & Belarus (355) \\
\hline 2006 & 1,309 & Belarus (366) \\
\hline 2007 & 2,645 & Ukraine (899) \\
\hline 2008 & 3,711 & Ukraine (921) \\
\hline 2009 & 3,070 & Belarus (726) \\
\hline $2010^{*}$ & 3,566 & Ukraine (823) \\
\hline $2011^{*}$ & 3,277 & China (1,125) \\
\hline $2012^{*}$ & 2,676 & Ukraine (729) \\
\hline
\end{tabular}

* In the years 2010, 2011 and 2012 the aggregate numbers for C, D and E type permits.

Source: Own elaboration based on the data from the Ministry of Labor and Social Policy.

The data contained in the Table 3.2 demonstrate that in the years 2004-2008 we dealt with regular growth in the number of permits issued to posted workers, while afterwards the situation stabilized. Presently the number of permits issued to this employee group is in the 2,5-3.5 thousand range.

As regards the number of permits for posted workers, nationals of Ukraine or Belarus prevailed for a long time. Since 2007 there has been also a steady growth in the number of permits issued to Chinese nationals. In 2011 the largest number of permits, namely almost 30 per cent - were issued to employees from China. This was related to deployment of several infrastructure investments by Chinese companies. In 2012 Ukraine returned to the first place.

\subsubsection{Declarations on intention to entrust a foreigner with a job}

As already suggested above, the introduction in Poland of declarations on intention to entrust foreigner with a job without necessity to apply for a work permit fundamentally changed the seasonal employment in Polish labor market. Since the entry into force of the declaration system, it has been the basis for statistics on temporary employment of employees from Ukraine, Belarus and Russia, since 2009 also from Moldova, and since 2010 - from Georgia. 
In the years 2004-2006 the interest of employers in lawful seasonal employment was marginal. The data concerning nationals of Ukraine, Russia and Belarus demonstrate that the number of citizens of those states employed for up to three months did not exceed 500, while in the case of employment for between 4 and 12 months - 3.5 thousand ${ }^{16}$. However, it must be assumed that this employment was actually at least several times higher, being located mainly in the grey zone. Nationals of those states came to Poland on the basis of issued tourist visas authorizing them to stay for not more than 90 days. They were not allowed to take a job in that period. It must be also assumed that some immigrants decided to stay in Poland although their visas expired, so both their stay and employment became unlawful.

\section{Figure 3.2. Number of declarations issued}

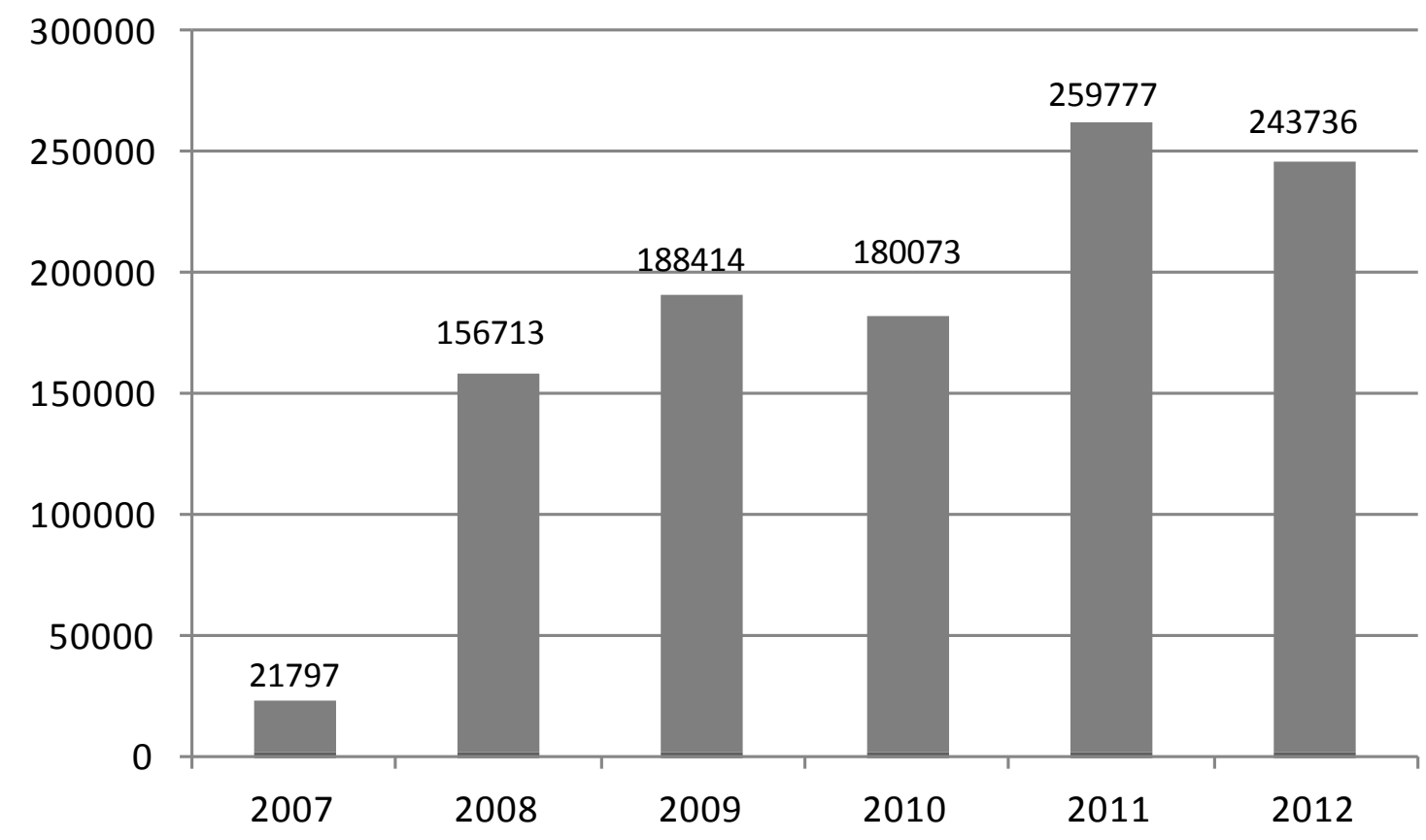

Source: Own elaboration based on the data from the Ministry of Labor and Social Policy.

After entry into force of the declaration system, the number of employees from Ukraine, Belarus and Russia began to rise dramatically. In 2007 21,797 declarations were registered. A year later the number went up to as many as 156,713. In consecutive years the dynamics of the number of registered declaration greatly slowed down, and in 2010 it was lower than in 2009 despite extension of the declaration-submission facility onto nationals of Moldova (2009) and Georgia (2010). In 2011 the number went up again, reaching the value of 259,777 declarations. The number of issued declarations dropped to 243,736 in 2012 (see Figure 3.2). The detailed data are contained in the Table 3.3.

\footnotetext{
${ }^{16}$ Data based on the statistics of the Ministry of Labour and Social Policy.
} 
Table 3.3. The number of declarations on intention to entrust a foreigner with a job, by nationality of worker, 2007-2012

\begin{tabular}{|l|l|l|l|l|l|l|}
\hline \multirow{2}{*}{ Year } & \multicolumn{5}{l}{ Nationality } & \multicolumn{5}{l|}{} \\
\cline { 2 - 7 } & Ukraine & Belarus & Russia & Moldova & Georgia & Total \\
\hline 2007 & 20,260 & 1,347 & 190 & 0 & 0 & 21,797 \\
\hline 2008 & 142,960 & 12,606 & 1,147 & 0 & 0 & 156,713 \\
\hline 2009 & 180,133 & 4,860 & 674 & 2,747 & 0 & 188,414 \\
\hline 2010 & 169,490 & 3,623 & 595 & 5,912 & 453 & 180,073 \\
\hline 2011 & 239,646 & 4,370 & 963 & 13,024 & 1,774 & 259,777 \\
\hline 2012 & 223,671 & 7,636 & 1,624 & 9,421 & 1,384 & 243,736 \\
\hline
\end{tabular}

Source: Own elaboration based on the data from the Ministry of Labor and Social Policy.

A decisive majority (approx. 92 per cent) of foreigners taking up temporary employment in Poland is comprised by Ukrainians (see Figure 3.3). In 2009-2011 there has been also a growth in the number of registered declarations for nationals of Moldova. The recent data shows increase of number of issued declarations for Belarusians. The employability scale for Russian and Georgians remains at very moderate levels. A decisive prevalence of Ukrainian nationals has been observed since the introduction of the declaration system. They are definitely the group that benefitted most from the system. We deal with a similar situation as concerns work permits. 
Figure 3.3. Year-to-year changes (in \%) in the number of declarations, by nationality (2008-2011)

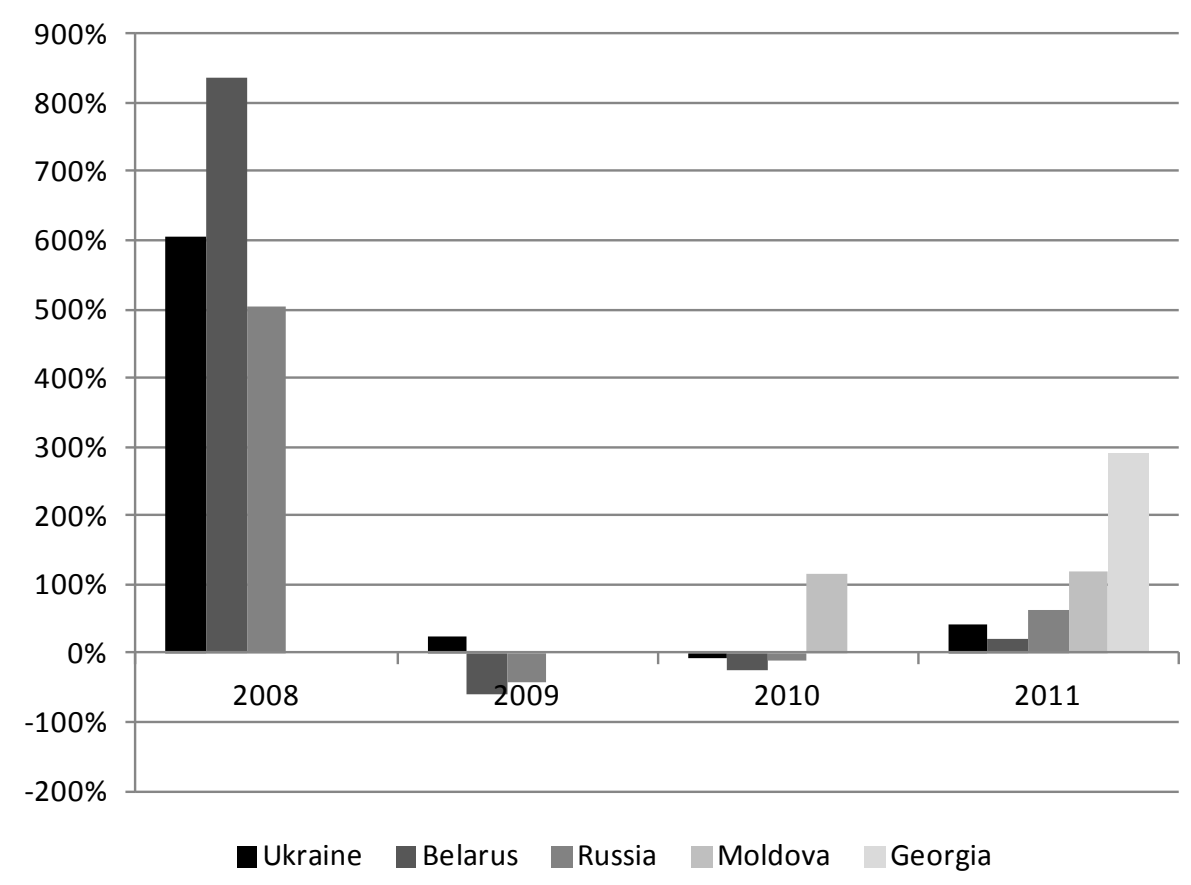

Source: Own elaboration based on the data from the Ministry of Labor and Social Policy.

Data presented above (Figure 3.3) clearly shows that the new regulation concerning inflow of short-term foreign labor to Poland is using as an efficient migration corridor and eventually allows to channel irregular immigration into legal forms of inflow. This is indicated by extremely high rates of change directly after the introduction of the rule - in 2008 in case of Ukrainians, Belarusians and Russians, in 2010 in case of Moldovans, and in 2011 in case of Georgians. Interestingly, the rising trend continues despite of visible signs of economic downturn.

The analysis of the registration of declarations with breakdown into consecutive months of 2011 demonstrates a notable seasonality of the employment of temporary foreign workers in Poland. The largest number of declarations is registered between February and May, the smallest in autumn and winter months. This follows from intentions of employers, who are interested in acquisition of this type of employees only in specified months. This concerns in particular sectors characterized by high seasonality of work intensity, namely agriculture, gardening and construction (see Figure 3.4.). 


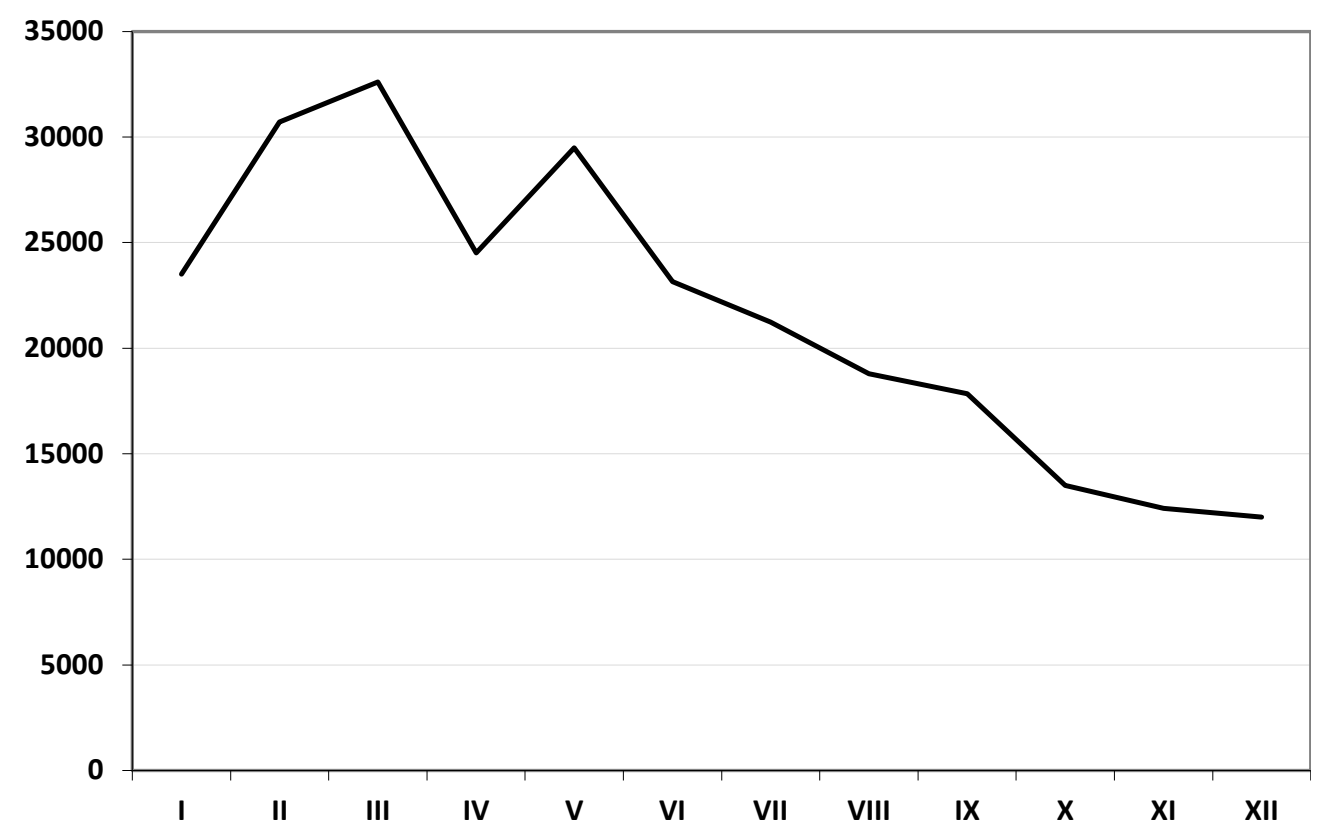

Source: Own elaboration based on the data from the Ministry of Labor and Social Policy.

3.3.3. Foreigners' employment in view of the data from the Social Insurance Institution A growth trend in foreigners' employability in the Polish market is corroborated by the data from the Social Insurance Institution (ZUS), according to which the number of people declaring citizenship other than Polish when notifying old-age pension insurance ${ }^{17}$ has been growing regularly. In 2008 the database of ZUS contained 65,041 registered foreigners, while in 2012 this number rose to 93,012 people. 18

On the basis of ZUS data one can also analyze the geographic structure of the resources of the foreigners working in Poland. Three groups have the largest representation therein:

- nationals of East European states (Ukraine, Belarus, Russia and Armenia);

- nationals of the largest EU-15 states (Germany and France) ;

- and nationals of the states of Eastern Asia (Vietnam and China).

Table 3.4. The most numerous nationalities among foreigners coming from third countries registered for old-age pension insurance - as of 31st December 2012

\begin{tabular}{|l|l|}
\hline $\begin{array}{l}\text { Nationality of the } \\
\text { insured }\end{array}$ & $\begin{array}{l}\text { Number of the insured } \\
\text { people }\end{array}$ \\
\hline
\end{tabular}

${ }^{17}$ According to the Central Register of the Insured.

${ }^{18} \mathrm{An}$ insured person is featured only once - regardless of the number of the codes of titles they are insured under. 


\begin{tabular}{|l|l|}
\hline Ukrainian & 29,713 \\
\hline Belarusian & 6,035 \\
\hline Vietnamese & 4,655 \\
\hline Russian & 3,661 \\
\hline Chinese & 3,094 \\
\hline Armenian & 1,756 \\
\hline Turkish & 1,719 \\
\hline Hindu & 1,242 \\
\hline
\end{tabular}

Source: Own elaboration based on the Central Register of the Insured (ZUS data).

In the groups mentioned in the Table 3.4 we can assume that their shares in the number of the insures are highly correlated with the power of economic ties with Poland, including in particular the presence in the labor market. In this connection the first place occupied by Ukrainian nationals comes as no surprise.

\subsubsection{Sectoral structure of foreigners' employment ${ }^{19}$}

In a majority of countries receiving migrant workers, their employment is cumulated in so-called second segment of the labor market. This means that foreigners take lowpaid jobs, with high risk of employment loss and of low prestige, which nationals of the receiving country are reluctant to take. Simultaneously some foreigners are employed in professions requiring very high qualifications, where supply of domestic workers is inadequate.

The analysis of the employment of foreigners holding work permits by sectors accordant with the sections of the Polish Classification of Activities ( $\mathrm{PKD}^{20}$ ) demonstrates that in 2011 the largest number of foreigners worked in construction, wholesale and retail trade and in households, probably as domestic help. Almost 50 per cent of all work permits were cumulated in those three sectors.

In the case of Ukrainians, who are the largest group among all third country nationals who were issued work permits, two sectors prevailed: construction (29.6 per cent of all employed) and household jobs (20.5 per cent of all employed).

The data concerning employment of foreigners with breakdown into PKD sections demonstrates that we are currently dealing in Poland with the onset of the formation of labor market segmentation, whereby foreigners take mainly simplejobs, while at

\footnotetext{
${ }^{19}$ See also section 4.2 .

20 In the forms covered with the studies performed by the Ministry of Labour and Social Policy, the following categories of economic activities are identified: agriculture, hunting and forestry; fishing; mining and quarrying; manufacturing; construction; trade and repair; hotels and restaurants; transport and communication; financial intermediation; real estate activities; education; health and social work activities. Full time strings are available for bolded ones.
} 
the same time some of them are present in professions requiring high qualifications. While the second segment of the labor market gives employment mainly to nationals of East European states, the first segment hires mainly nationals of OECD countries, but also of China and India. The aforementioned conclusion, concerning in particular employment in the secondary labor market, was corroborated by the analysis of data concerning declarations and foreigners registered for social insurance.

In the case of declarations on intention to entrust a foreigner with a job, i.e. one targeted at Eastern Partnership states, the largest number of them was registered in the sections of agriculture, forestry, hunting and fishing - almost 50 per cent, followed by construction ( 22 per cent). The data clearly demonstrate that in the case of this form of entrusting foreigners with a job, we deal mainly with their employment in the secondary labor market. This situation has not changed since the system entered into force. In 2008 the agricultural sector was indicated by 49.2 per cent of all employers registering a declaration on intention to employ a foreigner.

The sectoral structure of the employment of foreigners based on employers' declarations demonstrates strong regional diversification. Agriculture clearly dominates in Lubelskie, Świętokrzyskie, Łódzkie and Mazowieckie voivodeships. In eastern voivodeships there is hardly any employment of foreigners in manufacturing. At the same time employment in agriculture is much rarer in Śląskie, Zachodniopomorskie and Pomorskie voivodeships, where jobs in construction dominate.

\subsection{Legal employment of EAPs immigrants in Poland}

Figure 3.5 and Table 3.5 present structure of legal employment of foreigners admitted in 2011 on the basis of valid work permit. Total number of work permits issued amounted to around 41 thousand, out of them over 22 thousand (54\%) were issued to EAPs immigrants. 


\section{Figure 3.5. Structure of employment according to work permits, 2011}

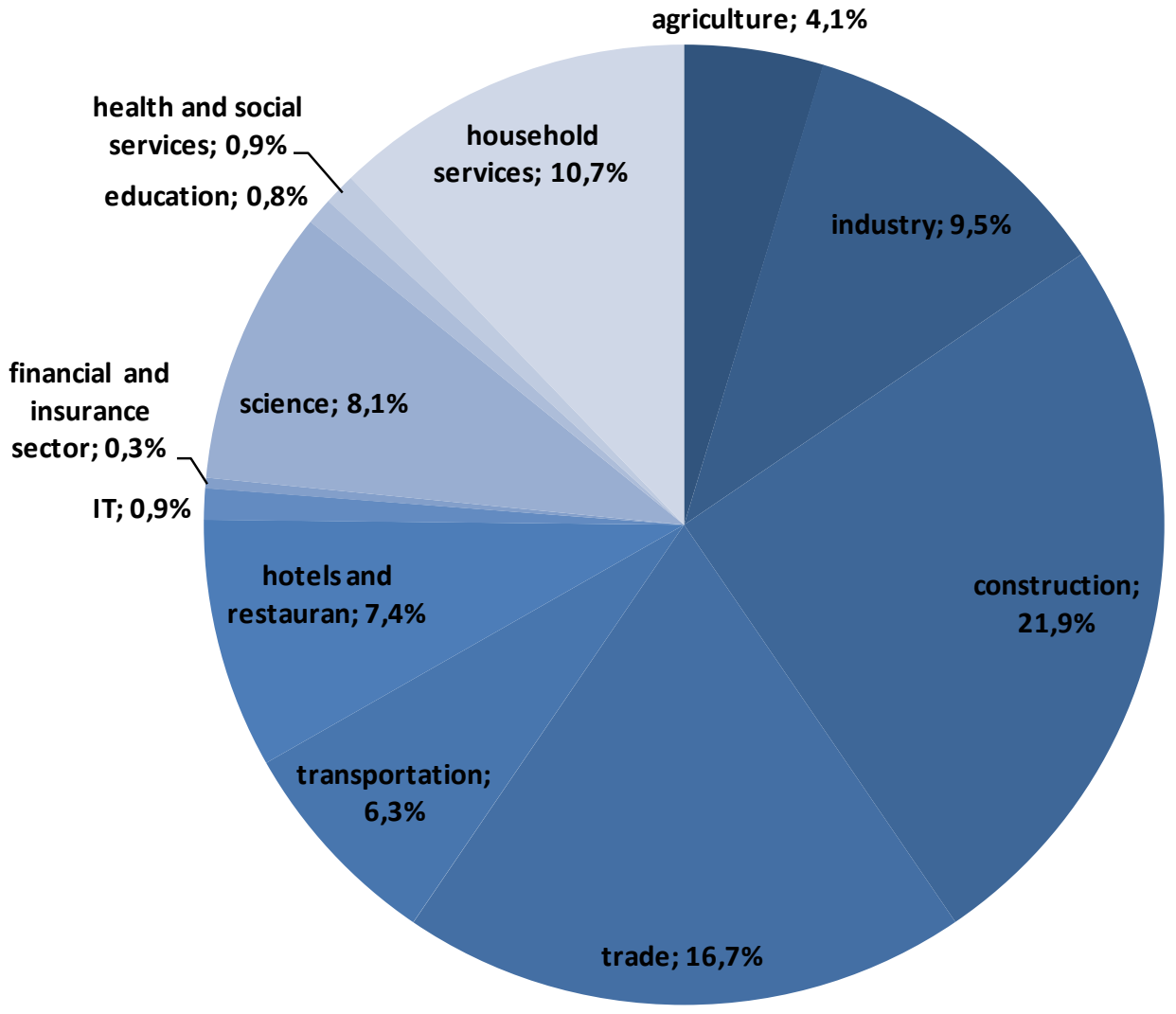

Source: Own elaboration based on the Ministry of Labor and Social Policy data.

The main sectors of employment in case of foreigners holding work permits constituted construction (almost $22 \%$ of the total) followed by trade (17\%), household services (11\%) and industry (10\%). Since 2004, i.e. Poland's accession into the EU and related changes in legislation concerning obligations to having work permits in case of the EU citizens, work permits are being issued predominantly for low skilled sectors (agriculture, industry, construction, trade, transportation, hotels and restaurants, and household services). In 2011 their share was as high as $80 \%$ of all work permits issued (see table below).

Table 3.5. Sectors of employment according to work permits issued, EAPs, 2011

\begin{tabular}{|c|c|c|c|c|c|c|c|c|c|c|c|c|c|}
\hline & $\begin{array}{l}\text { Number } \\
\text { of work } \\
\text { permits } \\
\text { issued }\end{array}$ & $\begin{array}{l}\text { agricul } \\
\text { ture }\end{array}$ & $\begin{array}{l}\text { indu } \\
\text { stry }\end{array}$ & $\begin{array}{l}\text { constr } \\
\text { uction }\end{array}$ & trade & $\begin{array}{l}\text { transpor } \\
\text { tation }\end{array}$ & $\begin{array}{l}\text { hotels and } \\
\text { restaurant } \\
\mathrm{s}\end{array}$ & IT & $\begin{array}{l}\text { financial } \\
\text { and } \\
\text { insuranc } \\
\text { e sector }\end{array}$ & $\begin{array}{l}\text { scienc } \\
\mathrm{e}\end{array}$ & $\begin{array}{l}\text { educ } \\
\text { atio } \\
\mathrm{n}\end{array}$ & $\begin{array}{l}\text { health } \\
\text { and } \\
\text { social } \\
\text { services }\end{array}$ & $\begin{array}{l}\text { household } \\
\text { services }\end{array}$ \\
\hline Total & 40808 & $4,1 \%$ & $9,5 \%$ & $21,9 \%$ & $16,7 \%$ & $6,3 \%$ & $7,4 \%$ & $0,9 \%$ & $0,3 \%$ & $8,1 \%$ & $\begin{array}{l}0,8 \\
\%\end{array}$ & $0,9 \%$ & $10,7 \%$ \\
\hline Armenia & 457 & $0,7 \%$ & $\begin{array}{l}2,0 \\
\%\end{array}$ & $8,8 \%$ & $51,6 \%$ & $2,4 \%$ & $7,4 \%$ & $0,2 \%$ & $0,7 \%$ & $2,2 \%$ & $\begin{array}{l}0,2 \\
\%\end{array}$ & $0,7 \%$ & $12,0 \%$ \\
\hline Azerbaijan & 55 & $3,6 \%$ & $5,5 \%$ & $10,9 \%$ & $41,8 \%$ & $1,8 \%$ & $20,0 \%$ & $0,0 \%$ & $0,0 \%$ & $7,3 \%$ & $1,8 \%$ & $0,0 \%$ & $0,0 \%$ \\
\hline Belarus & 1725 & $0,5 \%$ & $\begin{array}{l}3,2 \\
\%\end{array}$ & $14,7 \%$ & $9,3 \%$ & $41,0 \%$ & $1,0 \%$ & $2,5 \%$ & $0,2 \%$ & $3,1 \%$ & $\begin{array}{l}0,7 \\
\%\end{array}$ & $0,3 \%$ & $3,2 \%$ \\
\hline Georgia & 157 & $6,4 \%$ & $5,1 \%$ & $40,8 \%$ & $7,0 \%$ & $3,8 \%$ & $10,2 \%$ & $0,6 \%$ & $0,6 \%$ & $8,9 \%$ & 0,0 & $0,0 \%$ & $7,0 \%$ \\
\hline
\end{tabular}




\begin{tabular}{|l|l|l|l|l|l|l|l|l|l|l|l|l|l|}
\hline & & & & & & & & & & & $\%$ & & \\
\hline Moldova & 1017 & $4,4 \%$ & $9,5 \%$ & $24,7 \%$ & $1,7 \%$ & $22,4 \%$ & $0,8 \%$ & $0,1 \%$ & $0,0 \%$ & $10,7 \%$ & $0,1 \%$ & $0,0 \%$ & $11,8 \%$ \\
\hline Ukraine & 18669 & $6,3 \%$ & $9,1 \%$ & $29,6 \%$ & $6,8 \%$ & $6,9 \%$ & $2,3 \%$ & $0,3 \%$ & $0,1 \%$ & $7,6 \%$ & 0,3 & $1,3 \%$ & $20,5 \%$ \\
& & & & & & & & & & \\
\hline
\end{tabular}

Source: Own elaboration based on the Ministry of Labor and Social Policy data.

The structure of employment of EAPs immigrants is generally consistent with the general pattern of labor migration. However, there are several peculiarities worth noting:

1) The most important migrant sending country is Ukraine (almost $46 \%$ of all work permits issued).

2) On the other hand, number of work permits issued to citizens of Georgia and, particularly, Azerbaijan was extremely low ( $0.4 \%$ and $0.1 \%$ respectively).

3) In case of Armenia the most important sectors include trade and household services. This is the only EAP country with so large share of persons employed in trade sector.

4) Azerbaijanis (considering their low number) prefer trade, hotels and restaurants, and construction. Relative importance of scientific sectors is largely a statistical artifact (only 4 work permits issued).

5) Immigrants from Belarus tend to concentrate in transportation (this is the most important characteristics of this nationality), construction and trade.

6) Georgians are employed mostly in construction sector, the second most important sector comprises restaurants.

7) Immigrants from Moldova and Ukraine represent the most diverse structure of employment/

8) Moldovans are employed predominantly in construction, transportation, household services and scientific sector.

9) Ukrainians are recruited mostly to construction (almost 30\%) and household services (over 20\%) - a two-tier structure of the gendered labor market is thus clearly visible.

Table 3.6. Structure of employment according to work permits issued, EAPs, 2011

\begin{tabular}{|l|l|l|l|l|l|l|l|l|}
\hline \multicolumn{2}{|c|}{} & \multicolumn{3}{|l|}{ Skill level (selected groups) } & \multicolumn{3}{l|}{ Period of employment } \\
\cline { 3 - 9 } & $\begin{array}{l}\text { Professionals, } \\
\text { experts }\end{array}$ & $\begin{array}{l}\text { Qualified } \\
\text { workers }\end{array}$ & $\begin{array}{l}\text { Unqualified } \\
\text { workers }\end{array}$ & $\begin{array}{l}<3 \\
\text { months }\end{array}$ & $\begin{array}{l}\mathbf{3} \text { - 12 } \\
\text { months }\end{array}$ & $\begin{array}{l}\text { 1 - 2 } \\
\text { years }\end{array}$ & $\begin{array}{l}\text { over 2 } \\
\text { years }\end{array}$ \\
\hline Total & 36189 & $6,3 \%$ & $32,9 \%$ & $15,5 \%$ & $0,7 \%$ & $70,7 \%$ & $24,4 \%$ & $4,2 \%$ \\
\hline Armenia & 434 & $5,1 \%$ & $29,5 \%$ & $9,4 \%$ & $0,2 \%$ & $53,2 \%$ & $37,6 \%$ & $9,0 \%$ \\
\hline Azerbaijan & 47 & $6,4 \%$ & $40,4 \%$ & $0,0 \%$ & $0,0 \%$ & $68,1 \%$ & $27,7 \%$ & $4,3 \%$ \\
\hline Belarus & 1350 & $3,9 \%$ & $38,3 \%$ & $4,6 \%$ & $0,3 \%$ & $50,9 \%$ & $45,2 \%$ & $3,6 \%$ \\
\hline Georgia & 154 & $4,5 \%$ & $38,3 \%$ & $12,3 \%$ & $0,6 \%$ & $70,8 \%$ & $27,3 \%$ & $1,3 \%$ \\
\hline
\end{tabular}




\begin{tabular}{|l|l|l|l|l|l|l|l|l|}
\hline Moldova & 977 & $0,6 \%$ & $36,6 \%$ & $23,6 \%$ & $0,5 \%$ & $73,7 \%$ & $20,9 \%$ & $4,9 \%$ \\
\hline Ukraine & 17352 & $1,4 \%$ & $35,8 \%$ & $24,2 \%$ & $0,4 \%$ & $72,5 \%$ & $22,7 \%$ & $4,4 \%$ \\
\hline
\end{tabular}

Source: Own elaboration based on the Ministry of Labor and Social Policy data.

Most of the EAPs immigrants constitute workers (qualified or not). The highest share of unqualified workers was noted in case of immigrants from Moldova and Ukraine. Considering scale of the inflow from both countries it clearly indicates Polish labor market needs. Majority of immigrants holding work permits constitute short-term migrants, i.e. persons staying in Poland between 3 and 12 months. Share of such migrants is predominant in case of Ukraine and Moldova. Interestingly, in case of Armenian and Belarusian immigrants relatively large group of immigrants were admitted for the period up to 2 years (in case of Armenians additionally - over 2 years). This feature is to be closely related to sectors of employment of migrants originating from these countries (trade and transportation).

\subsubsection{Structural characteristics of Ukrainian migrants in Poland}

As clearly shown above, Ukrainians constitute the main important category - both with respect to the EAPs as well as in general terms - of immigrants to Poland. This is well understandable due to developmental gaps between Poland and its eastern neighbor, geographical location, cultural similarities and, last but not least, due to long lasting and strong migrant networks. The last feature is clearly identifiable when analyzing spatial distribution of immigrants in Poland.

Similarly to other EU countries immigrants are mostly drawn to big cities. This is why we observe a strong concentration of EAPs immigrants in Mazowieckie region (with Warsaw as the main immigration magnet), Małopolskie (with Kraków), Sląskie (with Katowice), and Pomorskie (with Gdańsk). However, in case of Ukrainian population there is a clear over-representation in case of a few regions with relatively weak economic potential - Podkarpackie and Lubelskie. This characteristic is to be explained while referring to the history of bilateral relations (mainly presence of ethnic Ukrainians and resettlement action in 1947- so-called "Akcja Wisła") and presence of migrant networks.

The most important feature of Ukrainian immigration to Poland is very strong concentration in the Warsaw area. In last few years between 30 and $50 \%$ of all applications for permanent residence permit in Poland were submitted in Mazowieckie voivodeship, the same holds true in case of work permits issued. This was one of the reasons why in 2010 a special survey dedicated to Ukrainian and Belarusian immigrants were undertaken in Warsaw area ${ }^{21}$. The next part of this

\footnotetext{
${ }^{21}$ The research was completed by the Centre of Migration Research within a research project "Mobility and migration at the time of transition: methodological challenges" (funded by the EEA financial scheme). The survey was based on the Respondent Driven Sampling (RDS) method as proposed by Heckathorn (1997) in order to overcome difficulties related to data on so-called hidden populations. One of the biggest advantages of this method was the (potential) ability to access not registered temporary migrants as well as illegal migrants. Altogether survey provides information on 546 individuals, while the largest subset constituted Ukrainians (439 individuals). Due to relatively low number of observations on Belarussians (and Russians) the analysis will be limited to Ukrainian immigrants only (see also Kaczmarczyk 2011). Similar survey was completed in 2012 - data courtesy of National Bank of Poland and Centre of Migration Research Foundation.
} 
section looks at characteristics of Ukrainian migrants using Respondent Driven Sampling (RDS) data. Obviously, this data sample is not representative for the total Ukrainian population in Poland but due to scarcity of data may serve as an important piece of information added to our knowledge on recent immigration to Poland.

Table 3.7 presents selected socio-demographic characteristics of a few categories of immigrants (including the RDS sample) vis a vis Polish population.

Table 3.7. The main socio-demographic characteristics of immigrants and Polish citizens, 2010 and 2012.

\begin{tabular}{|l|l|l|l|l|l|l|}
\hline Category & $\begin{array}{l}\text { \% of } \\
\text { males }\end{array}$ & \% of married & $\begin{array}{l}\text { \% of } \\
\text { persons } \\
\text { aged 15- } \\
\mathbf{3 5}\end{array}$ & $\begin{array}{l}\text { \% of } \\
\text { persons } \\
\text { aged 60 } \\
\text { and } \\
\text { more }\end{array}$ & $\begin{array}{l}\text { \% of } \\
\text { persons } \\
\text { with higher } \\
\text { education }\end{array}$ & employment \\
rate*
\end{tabular}

* For immigrants: share of immigrants with work permit valid above 3 month among immigrants registered for temporary stay above 3 month in Poland.

** Share of the immigrants in the RDS sample with working status.

Source: Fedoryshyn 2011 based on the data from Demographic yearbook 2009, Central Statistical Office and data from the RDS survey (CMR).

From the above presented data it follows that Ukrainian immigration to Poland is strongly feminized (particularly as compared to other categories of immigrants). Immigrants are young or very young (over $53 \%$ of them were younger than 35 years, only $1 \%$ of persons were older than 60 years), however over half of them were in stable relationships (mostly marriages). Ukrainians staying in Poland are relatively well educated or even very well educated as compared to the native population according to the RDS data over $25 \%$ of them were holding university degree. Last but not least, in case of this category of migrants the notion labor migrants' seems particularly well taken - over 85\% of Ukrainian migrants in the RDS sample were undertaking job while staying in Poland. This share is very high and even higher than the share of persons who declared work as the main purpose of stay in Poland (see Figure 3.6.). This is due to the fact that almost $20 \%$ of the sample constituted students who commonly participate in the Polish labor market. 
Figure 3.6. Immigrants from Ukraine in Warsaw by purpose of stay.

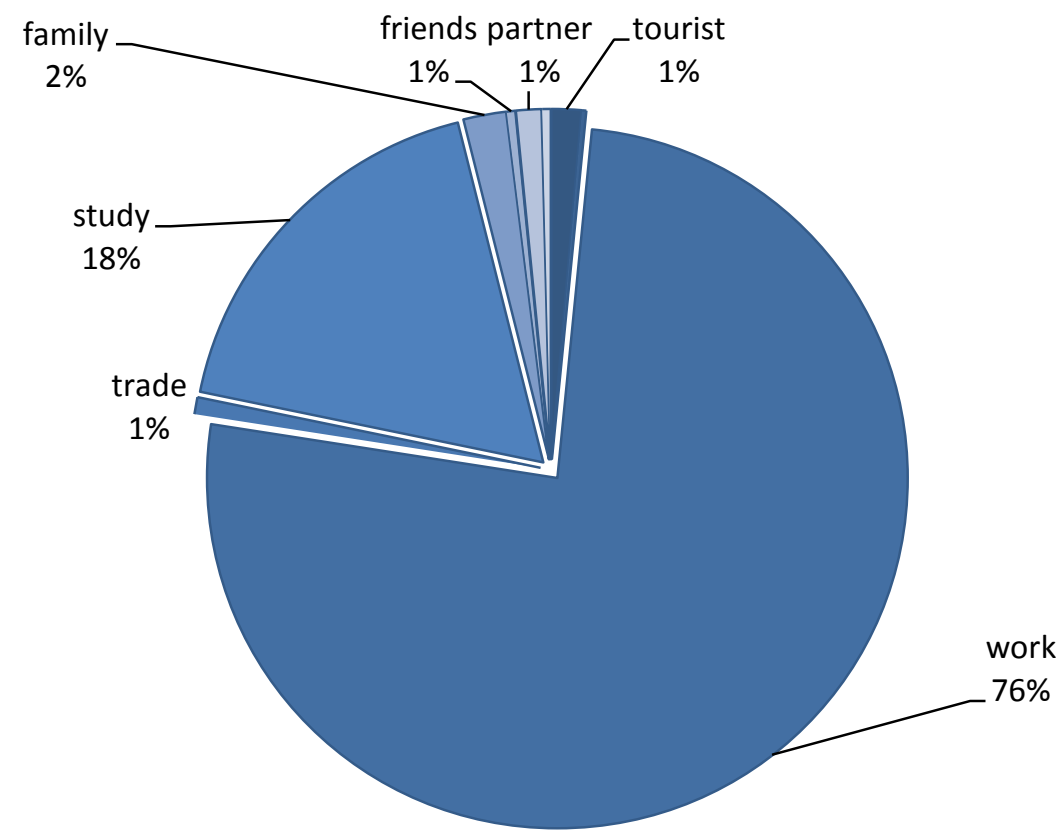

Source: Fedoryshyn 2011 based on the RDS survey, CMR

The next characteristic refers to structure of employment. Figure 3.7 presents the distribution of Ukrainian immigrants (RDS sample) according to the sector of employment.

Figure 3.7. Structure of employment of Ukrainian immigrants in Warsaw area (RDS sample 2010)

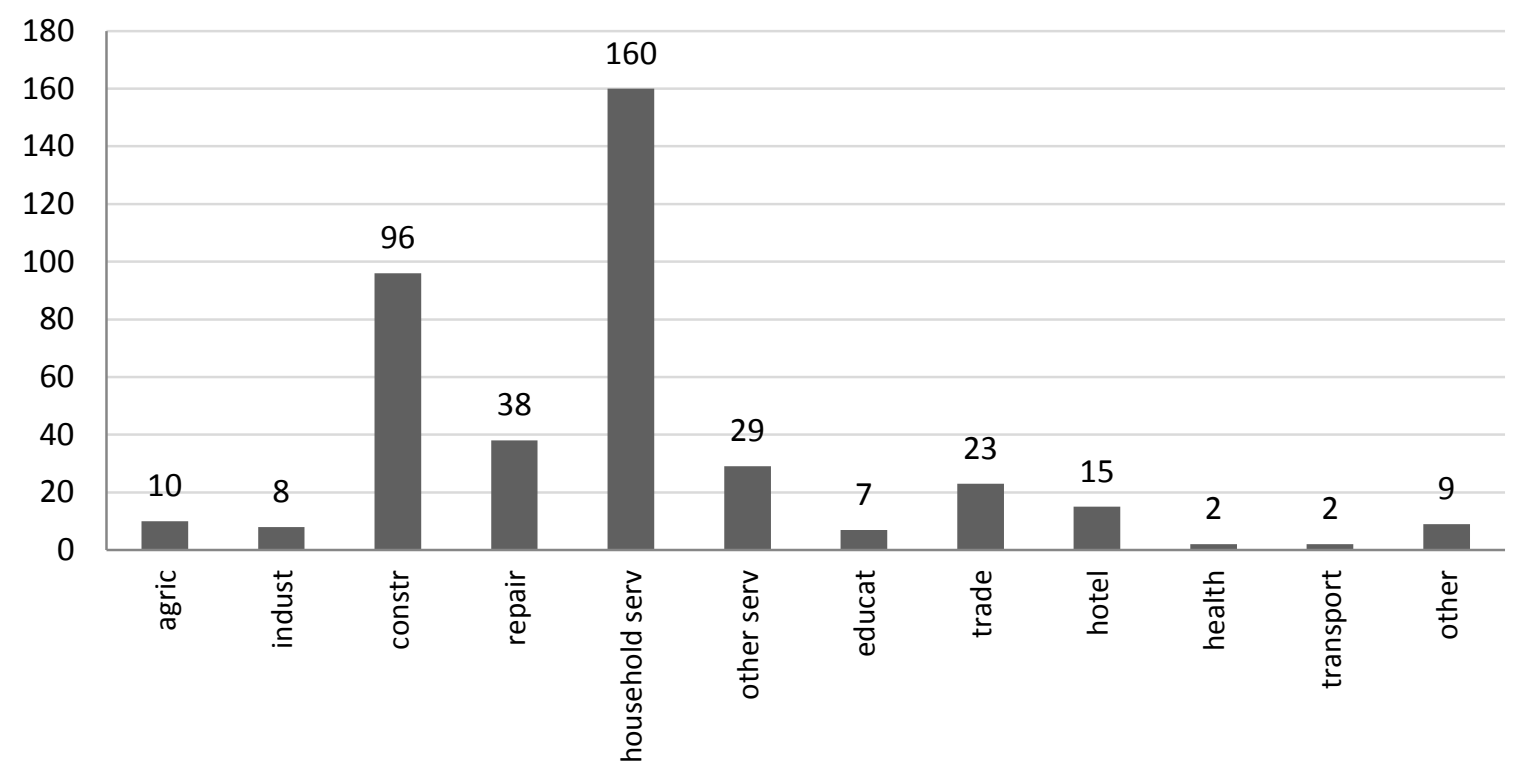

Source: Fedoryshyn 2011 based on the RDS survey, CMR 
As shown above over $41 \%$ of immigrants recorded during the survey were employed in private households ( $97 \%$ of these persons constituted women). The next important categories comprise construction workers ( $25 \%$ of immigrants, in this case almost exclusively men), persons employed for repair works (around 10\%) and in other services (7\%). Keeping in mind the specificity of the Warsaw area it is not strange that almost $6 \%$ of immigrants in the RDS sample were dealing with trade and merely $2 \%$ were employed in agriculture. Presented data is more or less coherent with the structure of employment as discussed above on the basis of work permits with an obvious over-representation of household services.

The RDS sample allows to tackle two important characteristics of Ukrainian immigrants which are extremely difficult to follow while using official data. Firstly, $75 \%$ of the Ukrainian labor immigrants in the RDS sample were staying in Warsaw for shorter than 12 months. This points to clearly to the temporary pattern of recent migration of Ukrainian citizens. Secondly, around $30 \%$ of the respondents captured by the survey were employed on irregular basis. Irregular immigrants from Ukraine were generally young (68\% aged between 18 to 40 ) and well educated ( $25 \%$ with tertiary education) persons who have arrived from western Ukraine. Additionally, majority of them (almost 80\%) were staying in Poland on short-term basis, i.e. for shorter than 6 months. According to the RDS sample $70 \%$ of all irregular migrants were women employed mainly in the personal households (dealing with domestic care, housekeeping or child care). Irregular male immigrants were employed mostly in the construction sector and repair works (Fedoryshyn 2011).

The last feature of the RDS sample, i.e. the ability to 'catch' irregular migrants is particularly important. There is a long lasting debate in Poland on the scale of irregular immigration from Ukraine. The problem is, however, that empirical evidence is lacking. As a consequence, estimates of the scale of irregular immigration from Ukraine vary from 50 thousand to even 300 thousand persons (Kus 2004, Frelak 2005).

\subsubsection{Persons who were admitted on the basis of simplified procedure (declarations)}

As shown above, since introduction (in 2006) the new legislation concerning seasonal employment in Poland on the basis of declarations issued by future employers, this particular form of employment became the main entry gate for migrants from the EAPs. Therefore it is important to follow selected characteristics of seasonal migrants collected by Polish local labor offices ${ }^{22}$.

Table 3.8 presents structural characteristics of seasonal workers from Ukraine who applied for declaration between 2007 and 2011. Contrary to other data sources, this particular data reveals relatively higher share of male migrants (particularly in 2007 when the share of persons employed in construction sector was the highest). The next feature is relatively high (and slowly rising) share of young migrants (aged 26 years or

\footnotetext{
${ }^{22}$ It is important to note that there is no validation mechanism responsible for testing whether information provided is correct. This refers both to socio-demographic characteristics as well as to sector of employment. This feature is a subject of scrutiny of Polish administration at the moment.
} 
less), while dominant category constitute migrants aged 26-40 years (almost 50\% in 2007, 45\% in 2011). Regarding sectors of employment, the highest number of seasonal workers from Ukraine is employed in agriculture (between 31 and 64\%). The next important sectors include construction (importance of this sector was decreasing but in 2011 the share amounted again to over $20 \%$ of all Ukrainian seasonal workers) and other (IT, experts employed in financial sector).

Table 3.8. Structural characteristics of Ukrainian seasonal workers, 2007-2011

\begin{tabular}{|l|l|l|l|l|l|l|}
\hline & Characteristics & $\mathbf{2 0 0 7}$ & $\mathbf{2 0 0 8}$ & $\mathbf{2 0 0 9}$ & $\mathbf{2 0 1 0}$ & $\mathbf{2 0 1 1}$ \\
\hline Sex & \% of women & $39,3 \%$ & $48,5 \%$ & $49,3 \%$ & $46,0 \%$ & $43,6 \%$ \\
\hline \multirow{4}{*}{ Age } & \% of persons aged <26 & $15,7 \%$ & $17,1 \%$ & $20,2 \%$ & $21,6 \%$ & $23,3 \%$ \\
\cline { 2 - 7 } & \% of persons aged 26-40 & $48,2 \%$ & $46,2 \%$ & $45,9 \%$ & $45,1 \%$ & $44,6 \%$ \\
\cline { 2 - 7 } & \% of persons aged 41-65 & $34,5 \%$ & $36,3 \%$ & $34,5 \%$ & $33,1 \%$ & $31,9 \%$ \\
\hline \multirow{3}{*}{$\begin{array}{l}\text { Sector of } \\
\text { employme (in \%) }\end{array}$} & agriculture & $31,3 \%$ & $51,8 \%$ & $66,4 \%$ & $63,6 \%$ & $52,8 \%$ \\
\cline { 2 - 7 } & construction & $24,6 \%$ & $14,3 \%$ & $9,8 \%$ & $10,4 \%$ & $21,3 \%$ \\
\cline { 2 - 7 } & private households & $6,0 \%$ & $5,3 \%$ & $4,7 \%$ & $3,7 \%$ & $4,6 \%$ \\
\cline { 2 - 6 } & trade & $3,3 \%$ & $2,3 \%$ & $1,7 \%$ & $1,2 \%$ & $1,6 \%$ \\
\cline { 2 - 6 } & industry & $13,4 \%$ & $6,2 \%$ & $3,3 \%$ & $3,2 \%$ & $5,2 \%$ \\
\cline { 2 - 6 } & transportation & $2,9 \%$ & $2,4 \%$ & $1,3 \%$ & $1,5 \%$ & $1,8 \%$ \\
\cline { 2 - 6 } & restaurants and hotels & $3,0 \%$ & $2,2 \%$ & $1,8 \%$ & $2,0 \%$ & $1,5 \%$ \\
\cline { 2 - 6 } & temp agencies & $4,8 \%$ & $6,9 \%$ & $6,0 \%$ & $5,8 \%$ & n.a.* \\
\cline { 2 - 6 } & other & $10,0 \%$ & $8,3 \%$ & $5,9 \%$ & $8,4 \%$ & $11,2 \%$ \\
\hline
\end{tabular}

* data for temporary work agencies were not collected for 2011

Source: Own elaboration based on the data provided by the Ministry of Labor and Social Policy.

In case of Belorussian seasonal workers the share of women is even lower than in case of Ukrainians and this is to be explained by relative importance of the transportation as a sector of employment. Share of persons aged below 26 years is relatively high (between 20 and 30\%) but almost 50\% of migrants constitute persons aged 26-40 years. The most important features relate to sectors of employment: Belarusian seasonal workers are employed mostly in transportation (around 25\% in 2010 and 2011) and construction (almost 50\% in 2007, over 20\% in 2011), i.e. clearly masculine sectors of economy. There is a growing number of Belarusian experts or professionals employed on the basis of simplified procedure visible (over $20 \%$ of the total in 2011 ).

Table 3.9. Structural characteristics of Belorussian seasonal workers, 2007-2011

\begin{tabular}{|l|l|l|l|l|l|l|}
\hline & Characteristics & $\mathbf{2 0 0 7}$ & $\mathbf{2 0 0 8}$ & $\mathbf{2 0 0 9}$ & $\mathbf{2 0 1 0}$ & $\mathbf{2 0 1 1}$ \\
\hline Sex & \% of women & $19,3 \%$ & $28,2 \%$ & $43,3 \%$ & $31,1 \%$ & $32,9 \%$ \\
\hline \multirow{4}{*}{ Age } & \% of persons aged <26 & $30,2 \%$ & $23,9 \%$ & $20,0 \%$ & $19,5 \%$ & $21,7 \%$ \\
\cline { 2 - 7 } & \% of persons aged 26-40 & $44,1 \%$ & $47,1 \%$ & $49,7 \%$ & $50,4 \%$ & $49,3 \%$ \\
\cline { 2 - 7 } & \% of persons aged 41-65 & $25,5 \%$ & $27,2 \%$ & $29,6 \%$ & $29,6 \%$ & $28,6 \%$ \\
\hline \multirow{2}{*}{\begin{tabular}{l} 
Sector of $\begin{array}{c}\text { employmen } \\
\text { t (in \%) }\end{array}$ \\
\cline { 2 - 7 }
\end{tabular}} & agriculture & $5,9 \%$ & $23,9 \%$ & $35,8 \%$ & $23,0 \%$ & $14,0 \%$ \\
\cline { 2 - 7 } & ponstruction & $46,7 \%$ & $26,2 \%$ & $12,9 \%$ & $12,3 \%$ & $20,7 \%$ \\
\cline { 2 - 7 } & private households & $1,6 \%$ & $5,0 \%$ & $6,8 \%$ & $4,7 \%$ & $3,0 \%$ \\
\hline
\end{tabular}




\begin{tabular}{|l|l|l|l|l|l|l|}
\hline & trade & $4,1 \%$ & $11,5 \%$ & $12,1 \%$ & $8,5 \%$ & $5,4 \%$ \\
\cline { 2 - 7 } & industry & $15,0 \%$ & $7,2 \%$ & $3,6 \%$ & $6,0 \%$ & $4,7 \%$ \\
\cline { 2 - 7 } & transportation & $10,5 \%$ & $9,1 \%$ & $11,3 \%$ & $24,2 \%$ & $25,9 \%$ \\
\cline { 2 - 7 } & restaurants and hotels & $3,7 \%$ & $3,8 \%$ & $6,1 \%$ & $7,1 \%$ & $6,1 \%$ \\
\cline { 2 - 7 } & temp agencies & $1,8 \%$ & $3,4 \%$ & $1,8 \%$ & $2,5 \%$ & n.a.* \\
\cline { 2 - 6 } & other & $11,3 \%$ & $7,9 \%$ & $9,2 \%$ & $12,5 \%$ & $20,3 \%$ \\
\hline
\end{tabular}

* data for temporary work agencies were not collected for 2011

Source: Own elaboration based on the data provided by the Ministry of Labor and Social Policy.

As shown below, Moldavian seasonal workers constitute the most feminized group (however the share of women is still below 50\%). It is also market by very high share of young migrants (almost $40 \%$ of all seasonal migrants from Moldova were younger than 26 years) and the size of this group was only slightly smaller than of the persons at mobile age.

Table 3.10. Structural characteristics of Moldavian seasonal workers, 2009-2011

\begin{tabular}{|l|l|l|l|l|}
\hline & Characteristics & $\mathbf{2 0 0 9}$ & $\mathbf{2 0 1 0}$ & $\mathbf{2 0 1 1}$ \\
\hline Sex & \% of women & $35,2 \%$ & $48,6 \%$ & $46,6 \%$ \\
\hline Age & \% of persons aged <26 & $32,0 \%$ & $37,2 \%$ & $39,2 \%$ \\
\cline { 2 - 5 } & $\%$ of persons aged 26-40 & $44,2 \%$ & $42,4 \%$ & $42,5 \%$ \\
\cline { 2 - 5 } & \% of persons aged 41-65 & $23,5 \%$ & $20,4 \%$ & $18,3 \%$ \\
\hline \multirow{3}{*}{$\begin{array}{l}\text { Sector of } \\
\text { employment }\end{array}$} & agriculture & $29,5 \%$ & $12,3 \%$ & $9,7 \%$ \\
\cline { 2 - 5 } & construction & $30,9 \%$ & $31,9 \%$ & $34,9 \%$ \\
\cline { 2 - 5 } & private households & $1,5 \%$ & $3,0 \%$ & $2,6 \%$ \\
\cline { 2 - 5 } & trade & $2,2 \%$ & $1,8 \%$ & $2,0 \%$ \\
\cline { 2 - 5 } & industry & $12,9 \%$ & $8,0 \%$ & $17,8 \%$ \\
\cline { 2 - 5 } & transportation & $1,4 \%$ & $1,9 \%$ & $2,0 \%$ \\
\cline { 2 - 5 } & restaurants and hotels & $1,6 \%$ & $7,7 \%$ & $3,3 \%$ \\
\cline { 2 - 5 } & temp agencies & $12,7 \%$ & $15,5 \%$ & n.a.* \\
\cline { 2 - 5 } & other & $7,4 \%$ & $17,9 \%$ & $27,7 \%$ \\
\hline
\end{tabular}

* data for temporary work agencies were not collected for 2011

Source: Own elaboration based on the data provided by the Ministry of Labor and Social Policy.

Moldavian seasonal migrants are employed predominantly in construction (almost $35 \%$ in 2011), industry and agriculture. Interestingly, agricultural sector responsible for almost $30 \%$ of the total inflow in 2009 is losing its importance (less than $10 \%$ in 2011) which may indicate that migrants from Moldova are trying to get access to other, more beneficial sectors. Indeed, in 2011 relatively large number of declarations recorder was related to professional and expert activities (sector: other)

Table 3.11. Structural characteristics of Georgian seasonal workers, 20102011

\begin{tabular}{|l|l|l|l|}
\hline & Characteristics & $\mathbf{2 0 1 0}$ & $\mathbf{2 0 1 1}$ \\
\hline Sex & \% of women & $32,2 \%$ & $42,6 \%$ \\
\hline \multirow{2}{*}{ Age } & \% of persons aged <26 & $17,0 \%$ & $19,0 \%$ \\
\cline { 2 - 4 } & \% of persons aged 26-40 & $45,7 \%$ & $48,0 \%$ \\
\hline
\end{tabular}




\begin{tabular}{|l|l|l|l|}
\hline & $\%$ of persons aged 41-65 & $37,5 \%$ & $32,8 \%$ \\
\hline \multirow{4}{*}{$\begin{array}{l}\text { Sector of } \\
\text { employmen }\end{array}$} & agriculture & $24,9 \%$ & $17,4 \%$ \\
\cline { 2 - 4 } & construction & $15,2 \%$ & $30,1 \%$ \\
\cline { 2 - 4 } & private households & $0,7 \%$ & $1,2 \%$ \\
\cline { 2 - 4 } & trade & $0,0 \%$ & $8,7 \%$ \\
\cline { 2 - 4 } & industry & $15,0 \%$ & $9,1 \%$ \\
\cline { 2 - 4 } & transportation & $9,9 \%$ & $3,7 \%$ \\
\cline { 2 - 4 } & restaurants and hotels & $3,8 \%$ & $2,0 \%$ \\
\cline { 2 - 4 } & temp agencies & $11,9 \%$ & n.a.* \\
\cline { 2 - 4 } & other & $18,5 \%$ & $27,8 \%$ \\
\hline
\end{tabular}

* data for temporary work agencies were not collected for 2011

Source: Own elaboration based on the data provided by the Ministry of Labor and Social Policy.

Citizens of Georgia can benefit out of the simplified procedure since 2010 and the number of declarations issued grew significantly since then. Georgian seasonal workers are mostly men (however, share of women increased in 2011) and are generally older than other EAPs seasonal migrants (almost 33\% of migrants aged 4165 years). The most important sectors of employment include construction (30\%) and agriculture (15\%). Similarly to Moldavians, in 2011 the role of agriculture was much smaller than before in favor of other sectors, particularly described as other (in case of Georgian migrants mostly IT specialists). 


\section{Costs and benefits of the EAPs immigration}

\subsection{Immigrants from EAPs - substitutes or compliments?}

While assessing the labor market impacts of immigration it is necessary to look at sectors of employment and to identify whether immigrants play complimentary or substitutive role as compared to native workers. Usually the complementary workforce is treated as beneficial and desirable (as it is supposed to fills in gaps on the host labor market). On the contrary, if foreigners are substitutes as compared to natives, it is presumed that they may push natives out of the labor market, increase the risk of being unemployed and create downward pressure on wages.

Due to relatively short history of inflow to Poland available literature and research on topic is extremely scarce. Notwithstanding, there are some structural features that have been identified. In early 2000s Iglicka (2000) proposed to analyze labor immigration to Poland while referring to three categories / labor market segments: 1) employment in the primary sector, i.e. highly qualified workers, managers, experts which was mostly the case of workers originating from the USA or EU countries, 2) employment in the secondary sector, i.e. low-skilled workers, seasonal workers - in this case coming predominantly from the former USSR countries, and 3) employment in both sectors which was specific for Vietnamese migrants (with an important role of ethnic economy and employment in almost exclusively two sectors: trade and catering). Anecdotal evidence (as well as outcome of the study quoted below) suggests this structure is still valid.

One of the rare opportunities to assess the role of immigrants on the Polish labor market was a nationally representative survey among Polish employers completed in 2007 by the CMR team (Kaczmarczyk 2009, Górny et al. 2010). Due to relatively large sample (around 5000 companies) and the fact that the sample included all sizes of companies (including micro size firms) it may serve as a basis for short discussion on the position of EAPs immigrants on the Polish labor market.

The survey revealed that Polish companies have very limited experience with employing foreigners. In case of real demand (i.e. real employment recorded in the past) the share of companies which employed foreigners was as high as $0.99 \%$. Potential demand (share of companies expressing interest / plans in employment of foreign workers) was slightly higher and equaled 3.3\%. It is difficult to assess whether this kind of outcome is a consequence of rising demand on foreign labor or rather particular climate concerning immigration (this was the time when new regulations so-called simplified procedure - were introduced under pressure of Polish farmers struggling with severe labor shortages and hoping to fill these gaps with immigrant seasonal workers). 


\section{Figure 4.1. Real and potential demand by firm size}

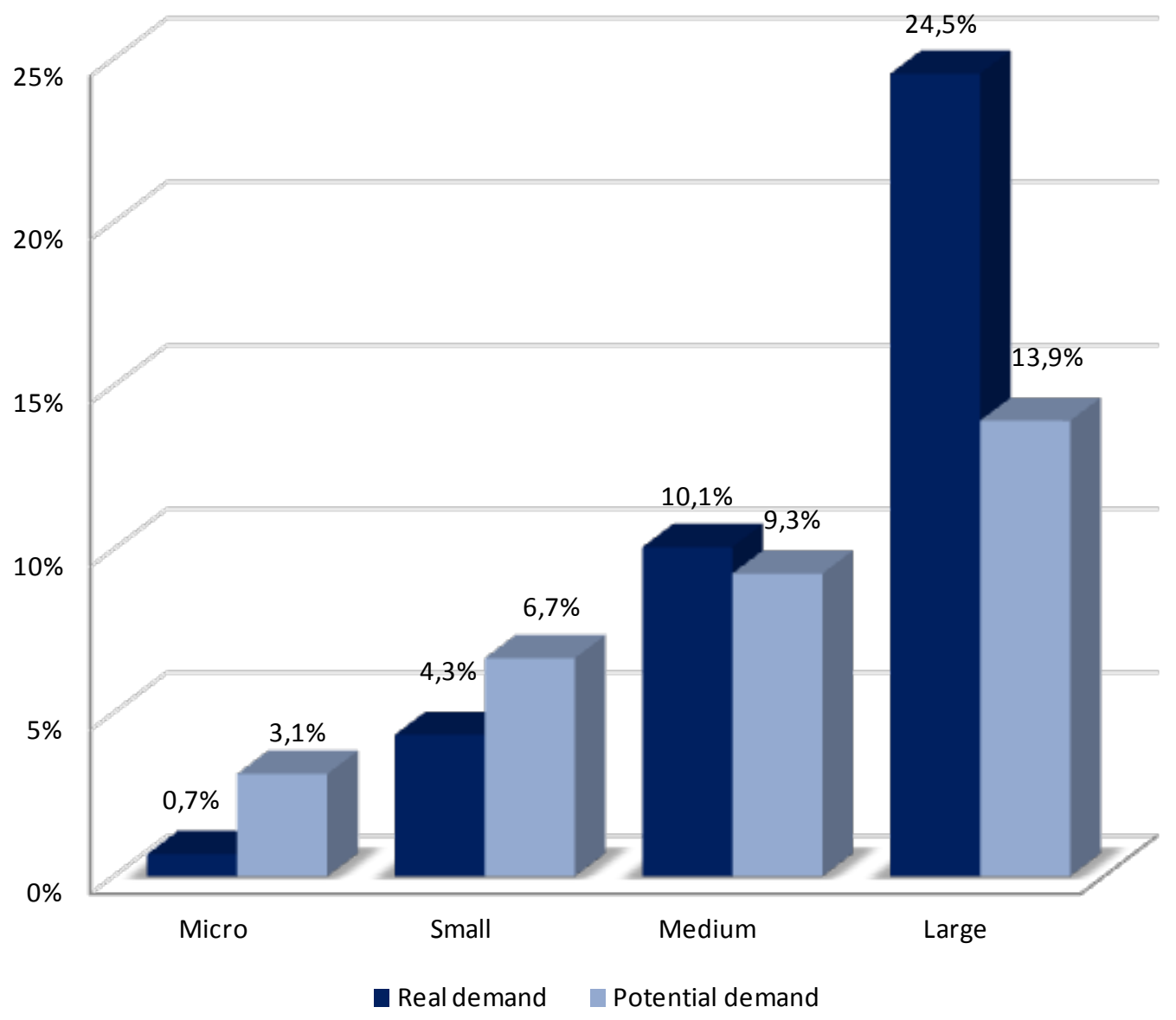

Source: Kaczmarczyk 2009.

Serious differences were noted as regards to the size of companies: in case of large firms the real demand was as high as $24.5 \%$ and the potential demand $-13.9 \%$, in case of medium size companies it was $10.1 \%$ and $9.3 \%$, in case of small firms $4.3 \%$ and $6.7 \%$ and for micro size companies $0.7 \%$ and $3.1 \%$ respectively - see Figure 4.1 . In all cases, however, average number of immigrants employed was low or very low, i.e. in case of large companies it amounted to 4.9 persons per company (Kaczmarczyk 2009).

According to the survey companies employing foreigners in Poland were concentrated in three main sectors: industry (mainly manufacturing), selected services (mainly trade), and public services (mainly education). There were some differences noted with regard to firm sizes, however, the general pattern was similar (see Figure 4.2). 
Figure 4.2. Real and potential demand by firm size and sector

\section{Real demand (employment)}
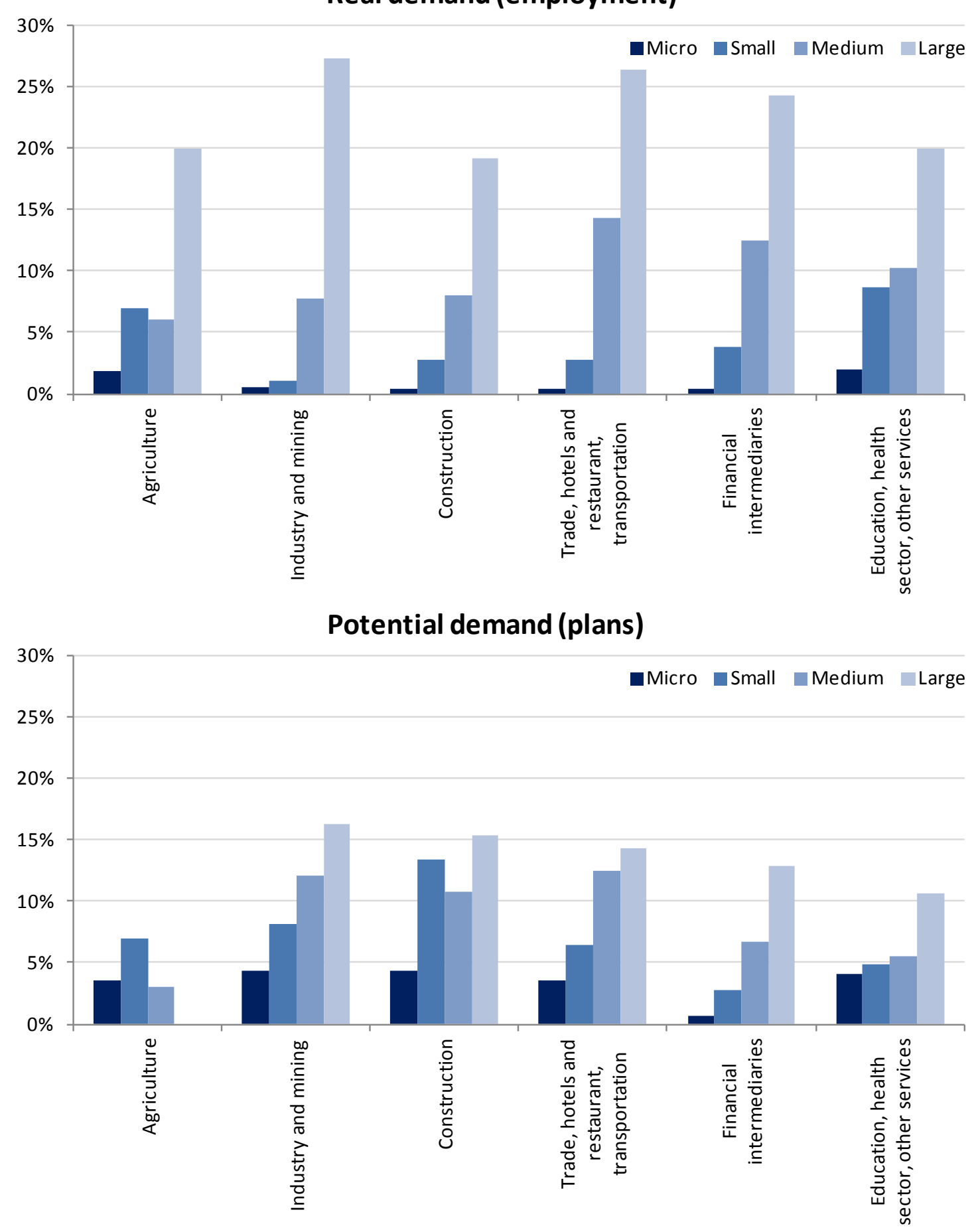

Source: Kaczmarczyk 2009.

In most cases there were two important immigrant groups - Ukrainians and Germans. Particularly Ukrainians dominated in case of all firm sizes - see Figure 4.3. 


\section{Figure 4.3. Real demand by firm size and country of origin}

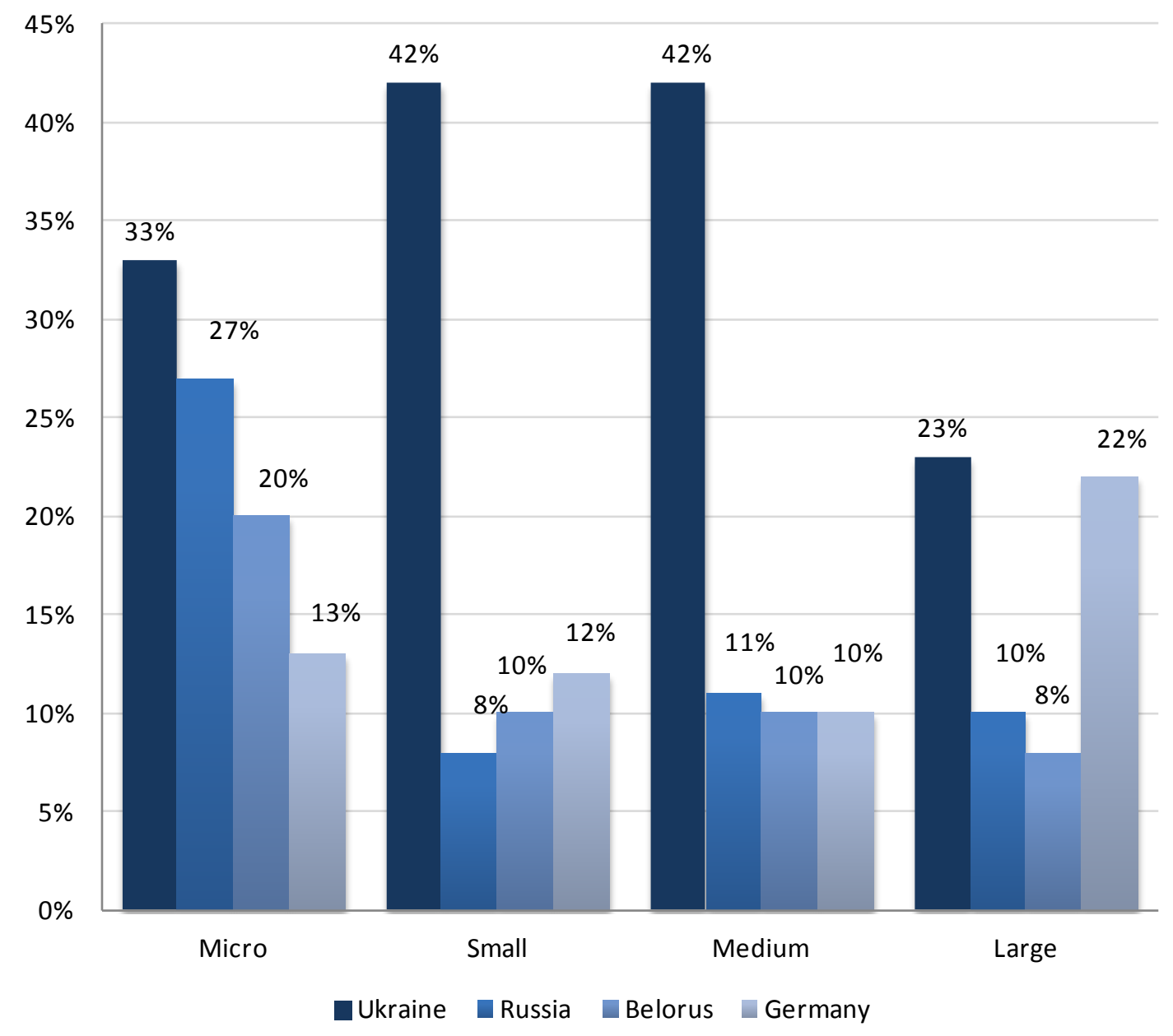

Source: Kaczmarczyk 2009.

As shown above, in all cases Ukrainian and Belarusian migrants were clearly the most important immigrant groups (except of large companies around 50\% combined). Germans were relatively important in case of large companies only. With regard to economic branches - Ukrainians played very important role in the industry and services (including public services, i.e. education).

The main aim of the analysis presented by J anicka and Kaczmarczyk (2010) was to look at the role played by immigrants on the labor market. Considering the fact that according to the survey data Ukrainians constituted the single most important immigrant category it seems reasonable to treat following discussion as an assessment of the position of EAPs immigrants on the Polish labor market.

J anicka and Kaczmarczyk (2010) have shown that employment patterns in Poland do not follow the dual labor market theory framework in a clear way. On the contrary, Figure 4.4 shows that most jobs offered to immigrants constituted posts demanding relatively high skills. 
Figure 4.4. Shares of firms employing foreigners in specific occupations, by firm size and type of demand (actual and planned)

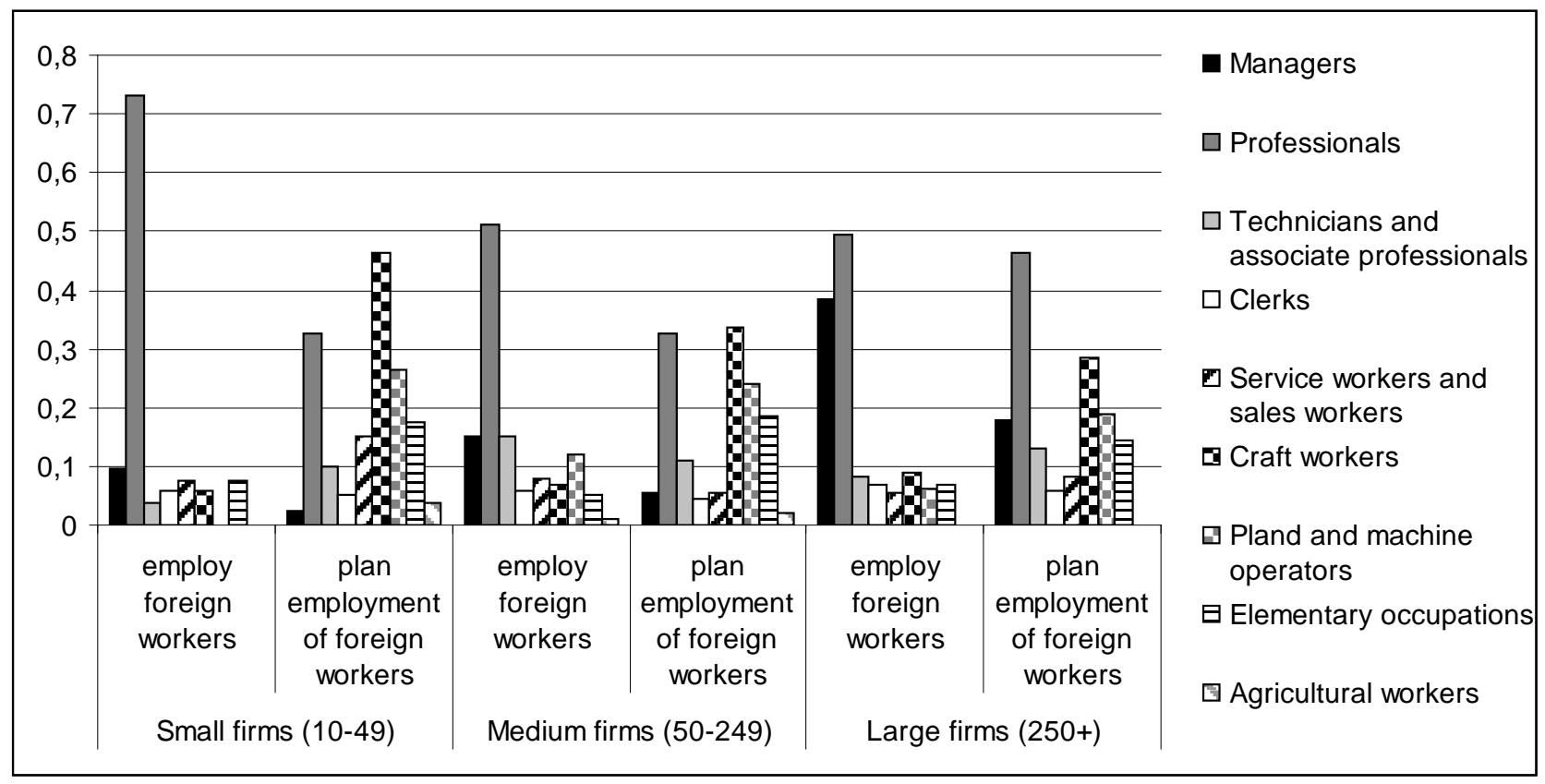

Source: J anicka and Kaczmarczyk 2010.

As shown above, according to the survey data foreigners were employed predominantly in managerial or professional positions and the employment levels of medium and low-skilled workers were relatively low. Notwithstanding, it is important to note that out of the three most important patterns of employment of foreigners (i.e. large or medium companies mostly with foreign capital, typical 'niches' of professions such as artists and illegal jobs in agriculture, trade, construction, domestic services) only the third one seems relevant in case of EAPs immigrants. And only this one can be described as a 'secondary' labor market with all its features (i.e. complementarity as compared to natives).

With regard to the characteristics of workplaces, J anicka and Kaczmarczyk (2010) have shown that immigrants and domestic workers were employed in very similar positions, with a small over-representation of foreigners in seasonal and temporary posts. Moreover, in most cases, the wages of immigrants employed by the Polish companies were similar (or even higher) to wages paid to the domestic workers - in fact, the share of immigrant workers with earnings lower than the earnings of Poles in analogous positions was lower than $20 \%$.

Thus it is extremely important to look at rationale for employing foreigners as well as character of jobs performed by them (in terms of modes of jobs creation). 


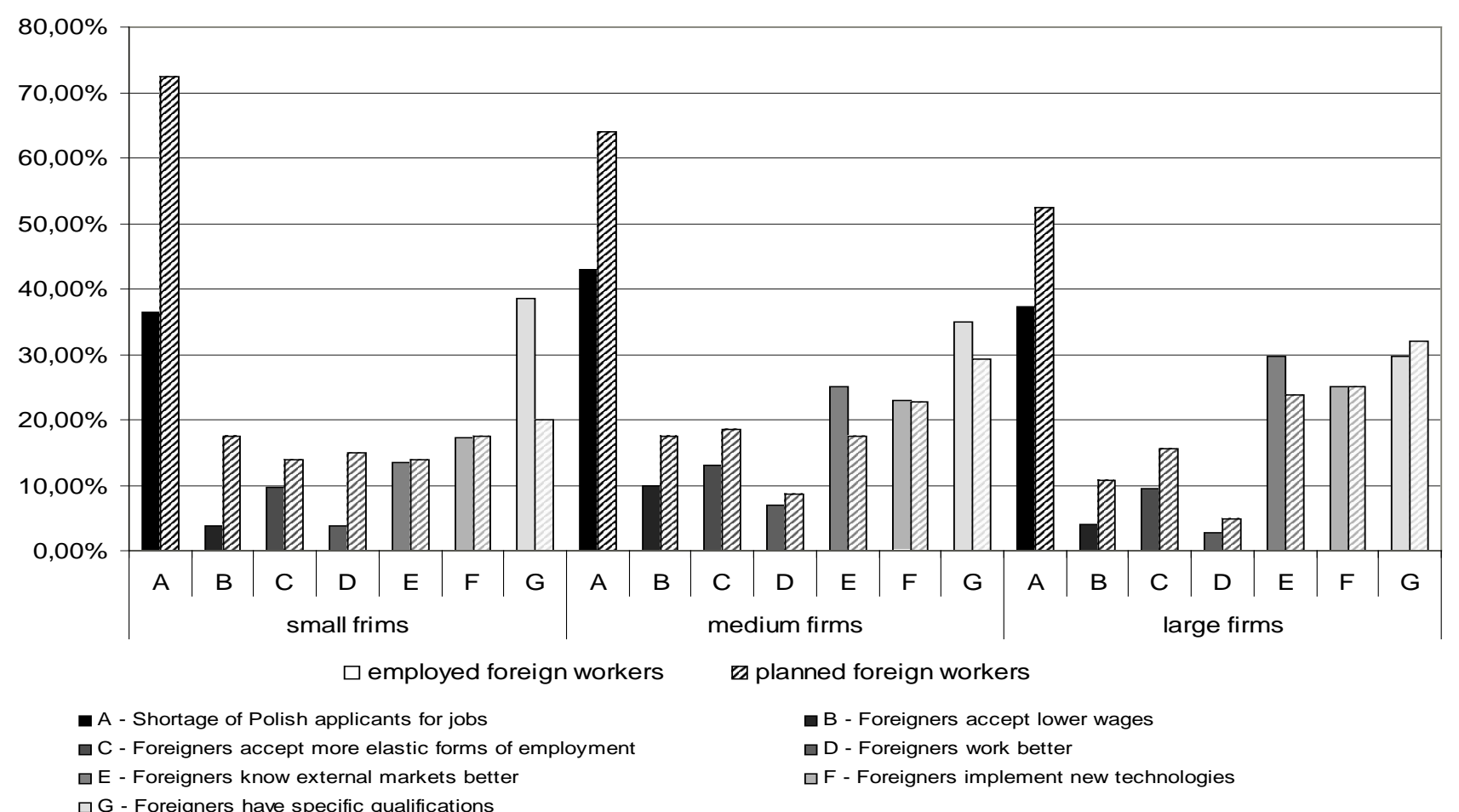

Source: Janicka and Kaczmarczyk 2010.

Figure 4.5 shows that in all cases employers who have had experiences with employing immigrants explicitly stated that the main rationale for employing a foreigner was the fact that migrant workers have specific skills. This would mean that immigrant labor is predominantly used to fill skill gaps in the Polish labor market. This conclusion is particularly well taken if we combine above mentioned category with following ones: a foreigner knowing external markets and new technologies better. All this means that main driver for looking for foreign workers were (so far) their specific (and unique) skills. This would also mean that immigrants play predominantly complementary role on the Polish labor market. Relatively small shares of companies declaring such motives as acceptance of lower wages or more flexible forms of employment are to be treated as clear sign that contrary to many Western European countries immigrants can hardly push natives out of the labor market (J anicka and Kaczmarczyk 2010). 


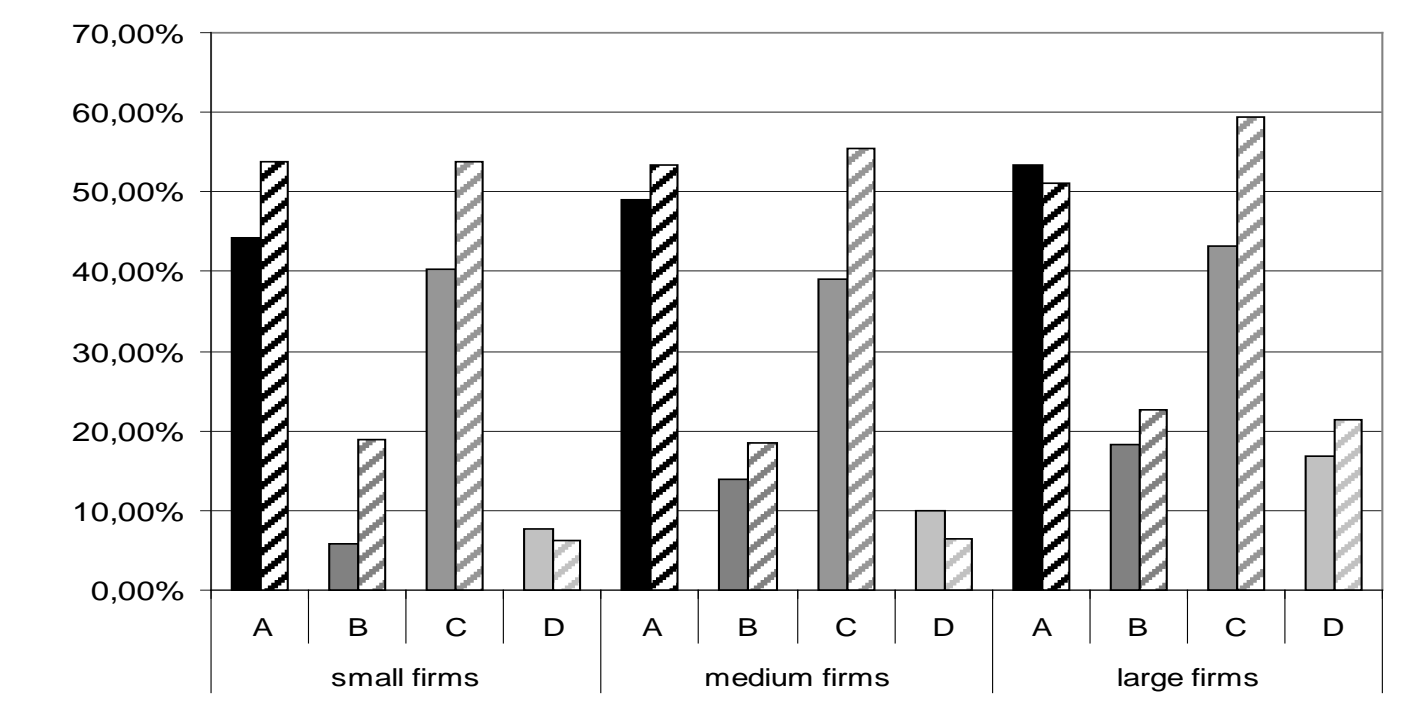

$\square$ employed foreign workers $\square$ planned foreign workers

A - Newly created jobs

$\square C$ - Jobs formerly occupied by Poles (who left) $\square$ B - Jobs formerly occupied by Poles (fired) $\square \mathrm{D}$ - Jobs formerly occupied by foreigners

Source: J anicka and Kaczmarczyk 2010.

Above presented conclusions are even strengthened when analyzing type of job places taken by immigrants (see Figure 4.6). From the presented data it follows that the most important impulse for seeking workers from abroad was the shortage of local workers (over $30 \%$ companies). Additionally, this argument seems to be increasingly important (definitely the most important category with regard to future demand). In fact, over $70 \%$ of small companies and $60 \%$ of medium size companies were expecting to have a chance to fill shortages of workers using foreign labor within the next year. A 'replacement strategy', i.e. employment of immigrants who occupied jobs previously performed by Polish workers was relatively rare (10-20\% of firms). From the data presented it follows that in most cases immigrants were employed at newly created posts or were filling posts left by Polish workers (in many cases this situation is to be linked with massive post-accession migration from Poland).

Last but not least, Polish employers rarely expressed clear preference toward employment of immigrant worker (while looking for a new one). Most of surveyed employers stated that they would prefer to employ Polish worker (including return migrants). Interestingly enough, however, between 25 and $40 \%$ of employers (depending on the company size) claimed that citizenship is not an important criterion when seeking new workers. As concluded by J anicka and Kaczmarczyk (2010), this outcome may suggest that there exists a significant potential demand for foreign labor, and along with positive developments in Polish economy one may expect increase in scale of labor immigration to Poland. 


\subsection{Skill mismatches and brain waste}

As clearly shown in chapter 3 the data on structural characteristics of the EAPs immigrants in Poland is extremely scarce. One of possible data sources is the RDS survey completed by the CMR in $2010^{23}$. It includes both data on the education level of immigrants from two EAPs - Ukraine and Belorussia - and their basic labor market characteristics.

Table 4.1 summarizes information on the level of education of Ukrainian and Belarusian immigrants in Warsaw area. It is important to note that contrary to most data sources, presented samples includes not only legal migrants but also irregular migrants. The share of temporary migrants in the sample was also relatively high. Notwithstanding, Table 4.1 reveals that immigrants from two most important EAPs (in terms of inflow) are relatively well educated - share of migrants with secondary education was as high as $68 \%$, share of persons with BA was as high as $11.3 \%$ and those holding at least MA amounted to $18 \%$.

Table 4.1. Level of education of the EAPs immigrants in Warsaw area

\begin{tabular}{|l|l|l|}
\hline Level of education & Number of observations & $\mathbf{\%}$ \\
\hline Elementary & 14 & 2,6 \\
\hline Vocational & 2 & 0,4 \\
\hline Secondary & 177 & 32,4 \\
\hline Secondary vocational & 193 & 35,3 \\
\hline BA & 62 & 11,3 \\
\hline MA or higher & 98 & 18,0 \\
\hline TOTAL & 546 & 100,0 \\
\hline
\end{tabular}

Source: Own elaboration based on the RDS survey - CMR 2010.

It is important to note, however, that out of the highly educated persons most of the respondents revealed education in area of humanities: linguistics (16\%), social sciences (12.5\%), economics and management (24\%), education (9\%), mathematics or nature science (9\%). Additionally there were $5 \%$ persons who claimed medical skills and 17\% technical skills. Most of these specializations are hardly useful on the 'emigration labor market', additionally there arise obvious problems with transferability of skills, i.e. difficulties in translating skills possessed into practical skills in case of low or inadequate language skills.

The next step will be to look at sectors of employment and try to assess skill usage of EAPs immigrants in Poland. Figure 4.7 presents the structure of employment according to the RDS survey data. As suggested already in previous section, the

${ }^{23}$ Survey was completed with RDS as a sampling method. 
structure of employment of migrants in the sample clearly mirrors the general pattern of immigrants' participation in the Polish labor market - almost 35\% of immigrants were employed in households (mostly women), next $23 \%$ in construction (mostly men).

Figure 4.7. Sectors of employment of EAPs immigrants in Warsaw area (RDS sample 2010), percentages

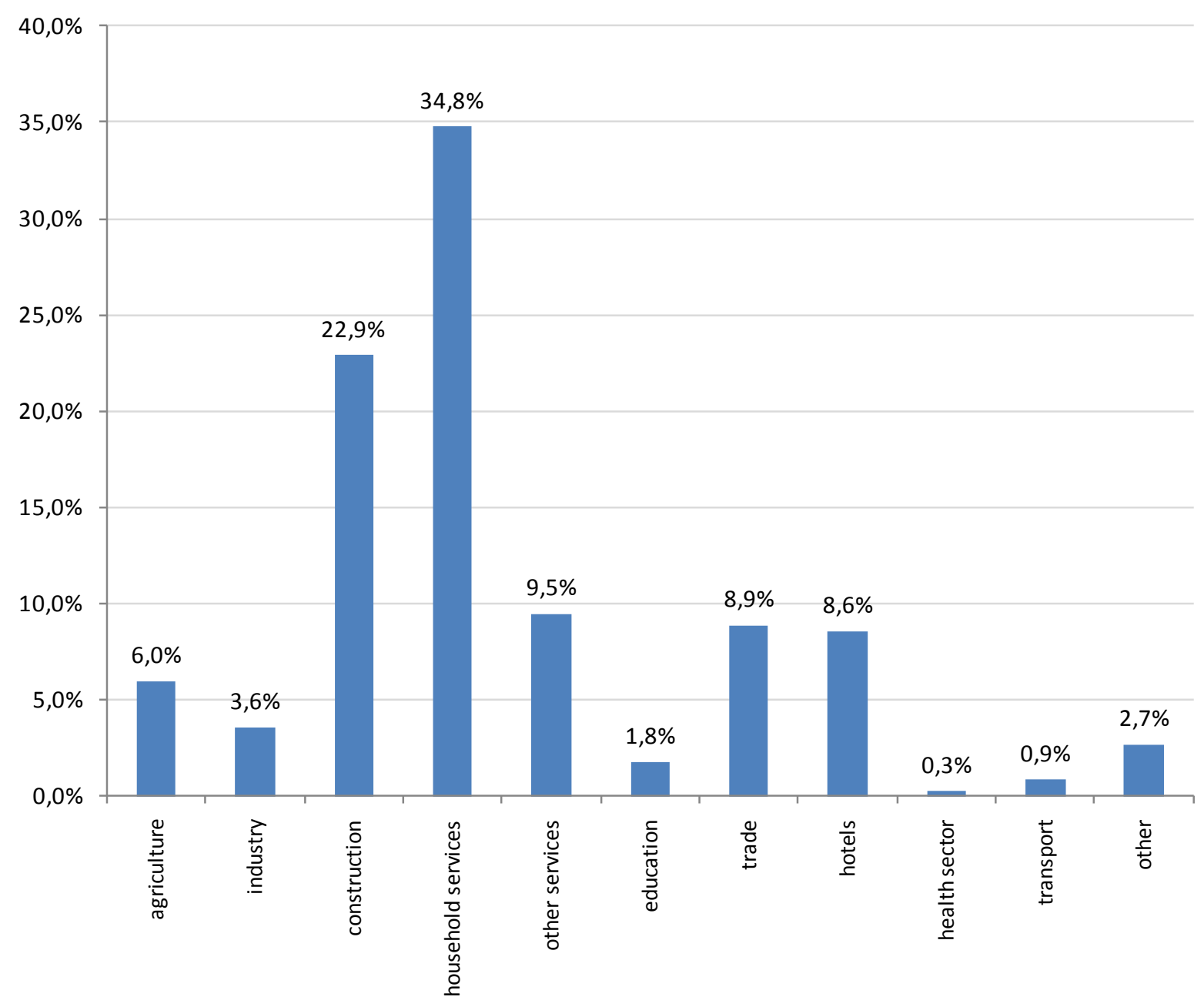

Source: Own elaboration based on the RDS survey - CMR 2010.

Table 4.2 looks at two dimensions which are critical while assessing skill utilization of immigrants - level of education and sector of employment. 
Table 4.2. EAPs immigrants in Warsaw area by sector of employment and education ( $R D S$ sample), in percentages

\begin{tabular}{|c|c|c|c|c|c|c|c|}
\hline \multirow{2}{*}{ Sector } & \multicolumn{6}{|c|}{ Level of education } & \multirow{2}{*}{ Total } \\
\hline & elementary & vocational & secondary & secondary vocational & BA & MA & \\
\hline agriculture & $7,1 \%$ & $0,0 \%$ & $9,1 \%$ & $5,6 \%$ & $0,0 \%$ & $5,9 \%$ & $6,0 \%$ \\
\hline Industry & $0,0 \%$ & $0,0 \%$ & $2,6 \%$ & $4,3 \%$ & $3,2 \%$ & $3,9 \%$ & $3,6 \%$ \\
\hline construction & $7,1 \%$ & $1,3 \%$ & $18,2 \%$ & $31,7 \%$ & $9,7 \%$ & $13,7 \%$ & $22,9 \%$ \\
\hline $\begin{array}{l}\text { household } \\
\text { services }\end{array}$ & $50,0 \%$ & $0,0 \%$ & $28,6 \%$ & $39,1 \%$ & $41,9 \%$ & $23,5 \%$ & $34,8 \%$ \\
\hline $\begin{array}{l}\text { other } \\
\text { services }\end{array}$ & $7,1 \%$ & $0,0 \%$ & $9,1 \%$ & $8,1 \%$ & $12,9 \%$ & $13,7 \%$ & $9,5 \%$ \\
\hline Education & $0,0 \%$ & $0,0 \%$ & $1,3 \%$ & $0,0 \%$ & $0,0 \%$ & $9,8 \%$ & $1,8 \%$ \\
\hline Trade & $14,3 \%$ & $0,0 \%$ & $13,0 \%$ & $5,6 \%$ & $3,2 \%$ & $15,7 \%$ & $8,9 \%$ \\
\hline Hotels & $7,1 \%$ & $1,3 \%$ & $14,3 \%$ & $5,0 \%$ & $22,6 \%$ & $2,0 \%$ & $8,6 \%$ \\
\hline $\begin{array}{l}\text { health } \\
\text { sector }\end{array}$ & $0,0 \%$ & $0,0 \%$ & $0,0 \%$ & $0,6 \%$ & $0,0 \%$ & $0,0 \%$ & $0,3 \%$ \\
\hline Transport & $0,0 \%$ & $0,0 \%$ & $2,6 \%$ & $0,0 \%$ & $0,0 \%$ & $2,0 \%$ & $0,9 \%$ \\
\hline Other & $7,1 \%$ & $0,0 \%$ & $1,3 \%$ & $0,0 \%$ & $6,5 \%$ & $9,8 \%$ & $2,7 \%$ \\
\hline Total & $100,0 \%$ & $2,6 \%$ & $100,0 \%$ & $100,0 \%$ & $100,0 \%$ & $100,0 \%$ & $100,0 \%$ \\
\hline $\mathbf{N}$ & 14 & 2 & 77 & 161 & 31 & 51 & 336 \\
\hline
\end{tabular}

Source: Own elaboration based on the RDS survey - CMR 2010.

From the above presented data it clearly follows that sector of employment does not reflect skills of EAPs immigrants. Regardless skill level majority of immigrant men are employed in construction (e.g. 10\% of persons with BA and $14 \%$ with MA) and majority of immigrant women in household services ( $42 \%$ of persons with BA and $24 \%$ with MA). The only sector when skills of migrants can be used in an adequate way is education (sector of employment of $10 \%$ of persons with MA).

To sum up, employment patterns of EAPs immigrants in Warsaw area are consistent with modes of labor market incorporation of immigrants as observed in most Western European countries. Even if the average level of education of the newcomers is relatively high (in many cases higher than in case of natives), sectors of employment reflect rather structure of demand than their skill structure. Thus, also in case of Poland we can claim brain waste rather than brain drain phenomenon. 


\subsection{General assessment of the labor market integration of the EAPs immigrants}

Before we will make an attempt to assess the impact of EAPs immigration on the Polish labor market and its consequences for future migratory inflows, it is important to stress a few points which seriously influence the whole understanding of this issue. Firstly, it needs to be clear that the scale of immigration to Poland is relatively low (including irregular flows). Secondly, the scale of legal inflow - i.e. the flow which is statistically measureable and which can be used in all kind of statistical / econometric exercises - is very or even extremely low as compared to the labor market size (see below). Thirdly, illegal employment - although higher in numerical terms than legal labor migration - is barely traceable in quantitative terms. All these issues make an assessment of the consequences of immigration an extremely difficult task, particularly if we need to refer to particular countries (e.g. EAPs) (J anicka and Kaczmarczyk 2010) ${ }^{24}$.

In the Polish labor market inflows to unemployment constantly predominant available number of vacancies. According to the data published by the Ministry of Labor and Social Policy (MLSP 2011) in the period 2007-2011 the vacancies corresponded to around 20-40 per cent of the inflow. That could suggest a permanent strong deficit of vacancies and consequently no space for employment of foreign workers. However, three additional factors should be taken into account:

- Only a fraction of vacancies is registered at labor offices. The real/full number is much larger but in principle unknown. That is typical also in other countries. In Poland that behavior of employers seeking workers is strengthen by a perception of long history of labor offices inefficiency.

- A substantial number of vacancies (mostly simple jobs) is created in the shadow economy. Its scale is still noticeable in Poland, relatively high at European standards.

- The number of vacancies vary. In certain sectors they virtually do not exist or are not reported (employers find workers without any contact with labor offices). There are also sectors in which vacancies are easily available and reported.

Given the above factors we can assume foreign workers can find jobs in the Polish labor market. However, we can analyze only the part of the market that is covered by official statistics.

The most extensive data on skill shortages are available in Reports published semiannually by the MLSP. They use a simple approach based on the following two formulas:

${ }^{24}$ Interestingly, J anicka and Kaczmarczyk (2010) claimed that problems with assessment of labour market impacts of immigration in case of Poland are not only consequence of the lack of appropriate data but also due to the fact that (im)migration theories are hardly applicable to the case of country with so limited scale of the (legal) inflow. 
1) Absolute deficit/surplus in a profession

$$
N_{i}^{k}=U_{i}^{k}-V_{i}^{k}
$$

Where: $\mathrm{N}$ - deficit/surplus (number of people); $\mathrm{U}$ - inflow into unemployment (number of unemployed); $\mathrm{V}$ - inflow of vacancies (number of vacancies); $\mathrm{k}$ - certain profession; i - period (in the publication $1^{\text {st }}$ or $2^{\text {nd }}$ half of the year)

2) Intensity coefficient of deficit/surplus in a profession

$$
W_{i}^{k}=\frac{V_{i}^{k}}{U_{i}^{k}}
$$

Where: $\mathrm{W}$ - coefficient of deficit/surplus; $\mathrm{U}$ and $\mathrm{V}$ as above

In the Reports it is assumed deficit professions have the coefficient $\mathrm{W}>1.1$, while surplus professions have $\mathrm{W}<0.9$. That applies to registered inflow of jobs and unemployed only.

Through the period 2007-2011 deficit professions were in such broad groups of professions as industry manual workers and craftsmen, while surplus professions were in groups such as simple jobs and services and retail workers. Again, as already stressed above, that covers only registered data.

Table 4.3. Number of unemployed and inflow (number of people

\begin{tabular}{|c|c|c|}
\hline Professions (broad groups, 1-digit) & $\begin{array}{l}\text { Number of unemployed } \\
\text { registered }\end{array}$ & $\begin{array}{l}\text { Percentage share in total } \\
\text { unemployment registered (\%) }\end{array}$ \\
\hline Total & $1,883,299$ & 100 \\
\hline Public authorities, higher staff & 9,753 & 0.5 \\
\hline Specialists & 156,775 & 8.3 \\
\hline Technicians and middle personnel & 237,618 & 12.6 \\
\hline Office personnel & 78,014 & 4.1 \\
\hline Service and retail workers & 318,49 & 16.9 \\
\hline $\begin{array}{l}\text { Agriculture, gardener, forestry, } \\
\text { fishermen }\end{array}$ & 37,561 & 2.0 \\
\hline Industry workers and craftsmen & 431,655 & 22.9 \\
\hline Machinery operators & 86,746 & 4.6 \\
\hline Simple jobs & 156,521 & 8.3 \\
\hline Armed forces & 1,03 & 0.1 \\
\hline No profession & 369,136 & 19.6 \\
\hline
\end{tabular}
registered in 1st half of 2011 - J une 2011) by 1-digit groups of professions

Source: Own elaboration based on the Ministry of Labor and Social Policy data.

The above presented data portray one of the most important features of the Polish labor market - namely manifold nature of observed mismatches. From the reports presented by the Ministry of Labor and Social Policy it follows that the deficit occupations (i.e. those in case of which vacancies were noted) include industry 
workers. At the same time (see Table 4.3) this kind of workers constitute the largest group of registered unemployed. This paradox is easier understandable when we consider that due to low scale of internal migration Polish local and regional labor markets are hardly connected.

According to literature the impact of immigrant workers on domestic employment and wages is typically relatively minor. An additional inflow of foreign workers do not push native workers out of jobs. It also does not substantially reduce wages of native workers even if they are close substitutes with immigrants. (see Friedberg and Hunt 1995). Also there is no evidence on a significant impact of immigration on unemployment (Lucchino et al. 2012). We do not have sufficient data to confirm these findings in the case of immigration to Poland. In this case it looks reasonable to assume a similar situation in the Polish labor market. Theoretical literature suggests the impact of immigrants on wages and employment of the natives mostly on depends human capital of the immigrants. This in turn suggests the impact of foreign workers can be larger than the one observed in developed Western countries since the difference in human capital of the immigrants and the natives can be smaller.

The number of registered vacancies in Poland is limited, low in comparison to the number of unemployed. Even if we take into account the most optimistic estimates of the number of unregistered vacancies there is no much space for immigrants. However, that do not hold in certain sectors, namely agriculture (seasonal workers), construction (also seasonal), cleaning works, etc. In these sectors a difference between human capital of native workers and immigrants is relatively smaller than in the majority of other more advanced sectors of the economy. A large part of jobs in that sectors is in shadow economy, so it is very difficult to present numbers. However, even if the numbers are significant we do not expect a significant impact on labor market situation as perceived by native workers.

In the context of presented analysis the most important is, however, that the labor market in Poland is large in terms of numbers. According to Labor Force Survey 2011 in the fourth quarter of 2011 the number of employed persons amounted to 16,291 thousands, unemployment was as high as 1,750 thousands. It is perfectly clear that numbers of immigrants to Poland are still very small as compared to the scale of the Polish labor market. Data on foreign workers in Poland show numbers that should not be compared since they are of totally different scale (legally working immigrants correspond to roughly 1-5 pro mille of the domestic labor force). Even correlation would be misleading since the fluctuations of employment and unemployment in the Polish labor market depend on other factors than the ones affecting immigration and legalization of immigrant status. Table 4.4 provides basic data on the Polish labor market and the number of legally working immigrants which clearly support above presented thesis. 
Table 4.4. Basic data on the Polish labor market and the number of legally working immigrants

\begin{tabular}{|c|c|c|c|c|c|c|c|}
\hline & $\begin{array}{l}\text { Average } \\
\text { monthly } \\
\text { wage/ sal } \\
\text { ars (in } \\
\text { PLN) }\end{array}$ & $\begin{array}{l}\text { Working } \\
\text { age } \\
\text { populatio } \\
\text { n }\end{array}$ & $\begin{array}{l}\text { Employme } \\
\text { nt ('000) }\end{array}$ & $\begin{array}{l}\text { Unemployme } \\
\text { nt ('000) }\end{array}$ & $\begin{array}{l}\text { Employme } \\
\text { nt rate (\%) }\end{array}$ & $\begin{array}{l}\text { Unemployme } \\
\text { nt rate (\%) }\end{array}$ & $\begin{array}{l}\text { Immigran } \\
\text { ts (legal) } \\
\text { ('000) }\end{array}$ \\
\hline 2007Q1 & 2709,14 & 31460 & 14839 & 1894 & 47,2 & 11,3 & \\
\hline 2007Q2 & 2644,34 & 31338 & 15152 & 1602 & 48,4 & 9,6 & \\
\hline 2007Q3 & 2703,41 & 31369 & 15432 & 1531 & 49,2 & 9,0 & \\
\hline 2007 Q4 & 2899,83 & 31402 & 15538 & 1448 & 49,5 & 8,5 & 14,1 \\
\hline 2008 Q1 & 2983,98 & 31424 & 15515 & 1361 & 49,4 & 8,1 & 39,2 \\
\hline 2008 Q2 & 2951,36 & 31330 & 15689 & 1196 & 50,1 & 7,1 & 51,0 \\
\hline 2008 Q3 & 2968,55 & 31354 & 15990 & 1132 & 51,0 & 6,6 & 39,9 \\
\hline 2008 Q4 & 3096,55 & 31383 & 16005 & 1154 & 51,0 & 6,7 & 26,6 \\
\hline 2009 Q1 & 3185,61 & 31403 & 15714 & 1414 & 50,0 & 8,3 & 65,0 \\
\hline 2009 Q2 & 3081,48 & 31454 & 15847 & 1355 & 50,4 & 7,9 & 58,1 \\
\hline 2009 Q3 & 3113,86 & 31479 & 16026 & 1404 & 50,9 & 8,1 & 40,1 \\
\hline 2009 Q4 & 3243,60 & 31505 & 15885 & 1471 & 50,4 & 8,5 & 25,2 \\
\hline 2010 Q1 & 3316,38 & 31521 & 15574 & 1839 & 49,4 & 10,6 & 54,9 \\
\hline 2010 Q2 & 3197,85 & 31708 & 15994 & 1682 & 50,4 & 9,5 & 64,7 \\
\hline 2010 Q3 & 3203,08 & 31725 & 16199 & 1627 & 51,1 & 9,1 & 42,8 \\
\hline 2010 Q4 & 3438,21 & 31741 & 16075 & 1649 & 50,6 & 9,3 & 17,6 \\
\hline 2011Q1 & 3466,33 & 31750 & 15875 & 1771 & 50,0 & 10,0 & 86,8 \\
\hline 2011Q2 & 3366,11 & 31853 & 16163 & 1690 & 50,7 & 9,5 & 77,1 \\
\hline 2011Q3 & 3416,00 & 31867 & 16284 & 1679 & 51,1 & 9,3 & \\
\hline 2011 Q4 & 3586,75 & 31884 & 16201 & 1750 & 50,8 & 9,7 & \\
\hline
\end{tabular}

Source: Own elaboration based on the CSO data and Ministry of Labor and Social Policy data.

That means foreign workers' impact on the Polish labor market irrespective to its characteristic is negligible (even if including relatively large numbers of seasonal workers). So applying theories, running sophisticated models and analyzing counterfactual scenarios would be just a purely technical exercise rather than a real research. Moreover, changes in numbers on immigrants legally working in Poland may depend on both changes of the number of immigrants and changes in their legal status. The two can hardly be separated in data.

There are, however, some interesting caveats. The vast majority of immigrants working in Poland come from EAPs. They usually speak Slavic languages that are more or less understandable for the Poles. So it is relatively easy to employ them in various types of housekeeping services25. As shown in previous sections sector of personal / household services is particularly important in case of Ukrainian immigrants (mainly female). However, it is worth stressing that sector did not exist even 10 years ago. It has been newly created as a consequence of an increase of relatively affluent families that can afford such services on one hand and a parallel

25 Typically, employing housekeeping services workers is not registered since it is easy to hide that. 
increase of supply of labor in that sector on the other. Importantly - it was possible only when costs of such services were relatively low due to the fact that they have been offered by immigrant labor force. This means that the inflow of immigrants contributed to the creation of the new sector in which the immigrants do not compete with native workers since the latter have virtually never been supplying labor in that sector at a significant level. The immigrants and the sector they work in appeared simultaneously. That looks very optimistic. Immigrants just fill a gap in the domestic market. There is no adverse effect on the native workers. As shown in previous sections - due to the scale of the migrant's inflow, the participation of immigrants in the Polish labor market is relatively low (the mechanisms observed now may change in the future along with a change of scale, but for now, no severe impacts on the economy may be observed) and, secondly, foreigners in most cases are employed because of their high or specific qualifications. Thus it is justified to conclude that so far complementarities has dominated over substitution effects.

\subsection{Impact of the EAPs immigration on the welfare system}

Assessment of all kind of impacts of the EAPs immigration to Poland is an extremely difficult task due to availability and the quality of migration data. This point is particularly well taken when considering such an aspect as potential impact of immigrants on the welfare system. Therefore, in this chapter first an attempt will be made to scientifically assess three areas related to the issue: 1) factors influencing wage level of EAPs immigrants, 2) factors responsible for their participation in tax base, i.e. legality of employment, and 3) estimation of the scale of potential beneficiaries of welfare payments in Poland. Second, outcomes of the study on net fiscal position of Ukrainian migrants will be discussed (Kaczmarczyk 2013). All issues will be analyzed based on the unique data set on Ukrainian immigrants in Poland as provided by the RDS samples completed in 2010 and 2012 (Kaczmarczyk 2011, 2013; Fedoryshyn 2011). Considering relative importance of the Ukrainian migrants this analysis may serve as an estimate of an overall impact of the EAPs immigration on the Polish welfare system.

Fedoryshyn (2011) analyzed factors responsible for the wage level of Ukrainian labor migrants in the Warsaw area (data as for 2010). She estimated Mincerian type wage equation including such factors as gender, education, legal status, and experience, command of Polish language and sectors of employment as regressors ${ }^{26}$. Three sets of estimates were presented including 1) only base set of regressors, 2) controls for sector of employment, and 3) controls for human capital specific for Poland (command of Polish language, education in Poland).

Results proved a positive and statistically significant impact of characteristics related to the human capital of immigrants on earnings. Hourly earnings were positively impacted by age (but at a decreasing rate), being married, level of education ${ }^{27}$ (both general as well as in case of education in Poland - the impact of the latter variable

\footnotetext{
${ }^{26}$ The dependent variable was logarithm of hourly earnings (average $=13$ PLN/ hour).

${ }^{27}$ Due to the available set of data no common instruments could be used in order to avoid endogeneity. Thus, obtained estimators may be biased.
} 
was much stronger, as expected), command of Polish language and experience on the Polish labor market (inverted u-shape).

Interestingly, in case of the Polish labor market Ukrainian men earn relatively less than women (according to the 2010 sample). This outcome is, however, mostly related to very significant differences in distribution of migrants across sectors and differences in wages offered in particular sectors. Thus, these differences become statistically insignificant when controlling for sectors of employment which are clearly gender-specific. According to the RDS 2010 data, employment in such sectors as agriculture, trade was connected with relatively lower hourly earnings, while such sectors as construction and household services were offering much better wages.

Next interesting characteristic refers to the number of visits in Poland which may be treated as a proxy of being circular or pendular migrant (very common pattern of migration among Ukrainians coming to Poland). According to the estimates provided by Fedoryshyn (2011), this variable impacted the mean wage level in a negative way which may suggest relatively more favorable position of those migrants with relatively stable status in Poland. This observation was confirmed by the positive impact of the variable indicating legal status of Ukrainian migrants in Poland - in all three specification legal workers from Ukraine earned relatively more than illegal ones.

Last but not least, outcomes of the model revealed that those persons who can rely on acquaintances in Poland and have been offered help with findingjob there earned relatively more than control groups. This confirms commonly presented hypothesis that recent migration from Ukraine is strongly driven by well-established and strong migrant networks (and that migrant networks positively impact on wages).

Regarding potential contribution to the state treasury, one of the most important questions refers to the factors responsible for being in a particular legal status ${ }^{28}$. In this case the possession of necessary documents to be able to work in Poland among Ukrainian immigrants was a proxy for being exposed to tax contribution. Similarly to previous case three specifications were estimated in order to control for Poland specific human capital and sectors of employment (Fedoryshyn 2011).

Results can be summarized as follows:

- Probability of being legally employed was higher among older migrants (inverse u-shape relationship);

- Human capital characteristics, including particularly command of Polish language, positively and significantly impacted the probability of being legally employed;

\footnotetext{
${ }^{28}$ Please, note that due to unique sampling method used (RDS), available data included around 30\% of irregular migrants which allowed to run this kind of analysis.
} 
- Probability of illegal employment was relatively higher among short-term or circular workers;

- Access to migrant networks was one of the most important variables explaining legality of employment (and this result may be surprising when considering mechanisms of obtaining job in Poland);

- Most importantly, probability of being legally employed was much higher among men than women. Similarly to previous case, however, this effect disappears when controlling for sectors of employment.

Sector of employment turned out to be one of the most important variable. Specifications including sectors specific control variables revealed that such sectors as household services, trade and transport are associated with relatively higher probability of being illegally employed, while being employed in construction, agriculture and other services, on contrary, increases the probability of legal employment. This is a clear evidence that recently introduced measures targeting workers in such sectors as agriculture and construction (declarations) are relatively efficient in terms of potential tax contribution of migrants.

The most challenging task is the estimation of the use of the welfare benefits by the immigrants from Ukraine. This is due to the fact that available data does not allow to provide a comprehensive and in-depth analysis of this phenomenon. This is why Kaczmarczyk (2013) attempted to assess the net fiscal position of Ukrainian immigrants in Poland on a basis of dedicated survey completed according to the RDS methodology commonly used in case of rare, "hidden", or hard to reach populations. 29

In the following section we attempt to assess the net fiscal position of Ukrainian immigrants in Poland, i.e. we compare the transfers made to a given group considered against all payments made (taxes and contributions to the pension system) ${ }^{30}$. Contrary to other approaches (Dustmann et al. 2010; Barrett and Maitre 2011; OECD 2013) the assessment is made on real values of payments/ benefits. Alternative empirical strategy would imply spreading the costs and benefits among the immigrants and natives. This strategy, however, would be highly questionable considering the fact that aggregate immigration data in case of Poland is not reliable and can lead to seriously biased results.

All in all three alternative scenarios were presented, Table 4.5:

\footnotetext{
${ }^{29}$ Data collected include comprehensive information on around 500 Ukrainian immigrants, including their detailed migration trajectories, family situation (in Poland and Ukraine), labor market participation, remittances, social benefits claimed and migrant networks. Survey data was collected on individual basis but for sake of the analysis of the fiscal impacts of migration there were supplemented with the data on elderly and dependents household members present in Poland (imputed data) (for more details see Kaczmarczyk 2013).

${ }^{30}$ As usually in such cases all available data was used but still imposition of a number of assumptions and imputations was inevitable (see Kaczmarczyk 2013).
} 
Table 4.5. Net fiscal position of Ukrainian immigrants in Poland scenarios considered

\begin{tabular}{|l|l|l|}
\hline Scenario I & \multicolumn{1}{|c|}{ Revenues side* } & \multicolumn{1}{|c|}{ Expenditures side } \\
& $\begin{array}{l}\text { Payments of taxes and other payments (social } \\
\text { calculated only for those claiming taxes } \\
\text { payment in Poland (calculations based on } \\
\text { reported values) }\end{array}$ & $\begin{array}{l}\text { Only those immigrants who self-reported } \\
\text { the take-up of social remittances are } \\
\text { considered (calculations based on } \\
\text { reported values) }\end{array}$ \\
\hline Scenario II & $\begin{array}{l}\text { Payments of taxes and other payments (social } \\
\text { security payments, health security payments) } \\
\text { calculated for those migrants who were } \\
\text { staying in Poland legally and were actually } \\
\text { working (calculations based on reported and } \\
\text { imputed values) }\end{array}$ & $\begin{array}{l}\text { All immigrants theoretically eligible are } \\
\text { considered. Two level conditions were } \\
\text { applied: first, only persons legally staying } \\
\text { in Poland were considered as eligible, and } \\
\text { second, specific rules were applied } \\
\text { (persons below income threshold in case } \\
\text { of cash benefits, persons at retirement age } \\
\text { in case of pensions, persons with } \\
\text { dependents in case of children benefits) } \\
\text { (calculations based on reported and } \\
\text { imputed values) }\end{array}$ \\
\hline Scenario III & $\begin{array}{l}\text { Payments of taxes and other payments (social } \\
\text { security payments, health security payments) } \\
\text { calculated for those migrants who were } \\
\text { actually working (i.e. same as scenario II but } \\
\text { irrespective of the legal status of a given } \\
\text { person) (calculations based on reported and } \\
\text { imputed values) }\end{array}$ & $\begin{array}{l}\text { All immigrants theoretically eligible are } \\
\text { considered irrespective their legal status } \\
\text { (i.e. same as scenario II except for the } \\
\text { legal status condition) (calculations based } \\
\text { on reported and imputed values) }\end{array}$ \\
\hline
\end{tabular}

* Indirect taxes not considered due to lack of data on consumption structure

Source: Kaczmarczyk 2013.

It is clear that scenarios considered differ with respect to the source of information (self-reported or imputed) - scenario II versus scenario I. Additionally, scenario III assumes that all immigrants are legalized and thus it can be useful for policy considerations. Outcomes of the analytic procedure are presented below, Figure 4.8. Importantly, they should not be generalized because of two facts. First, data used refer to one particular immigrant group which does not reflect the whole complexity of recent immigration to Poland. Second, the analysis was designed as a static approach and thus refers to 2012 only. 
Figure 4.8. Net fiscal position of Ukrainian migrants in Poland, by age groups, in PLN (annually)

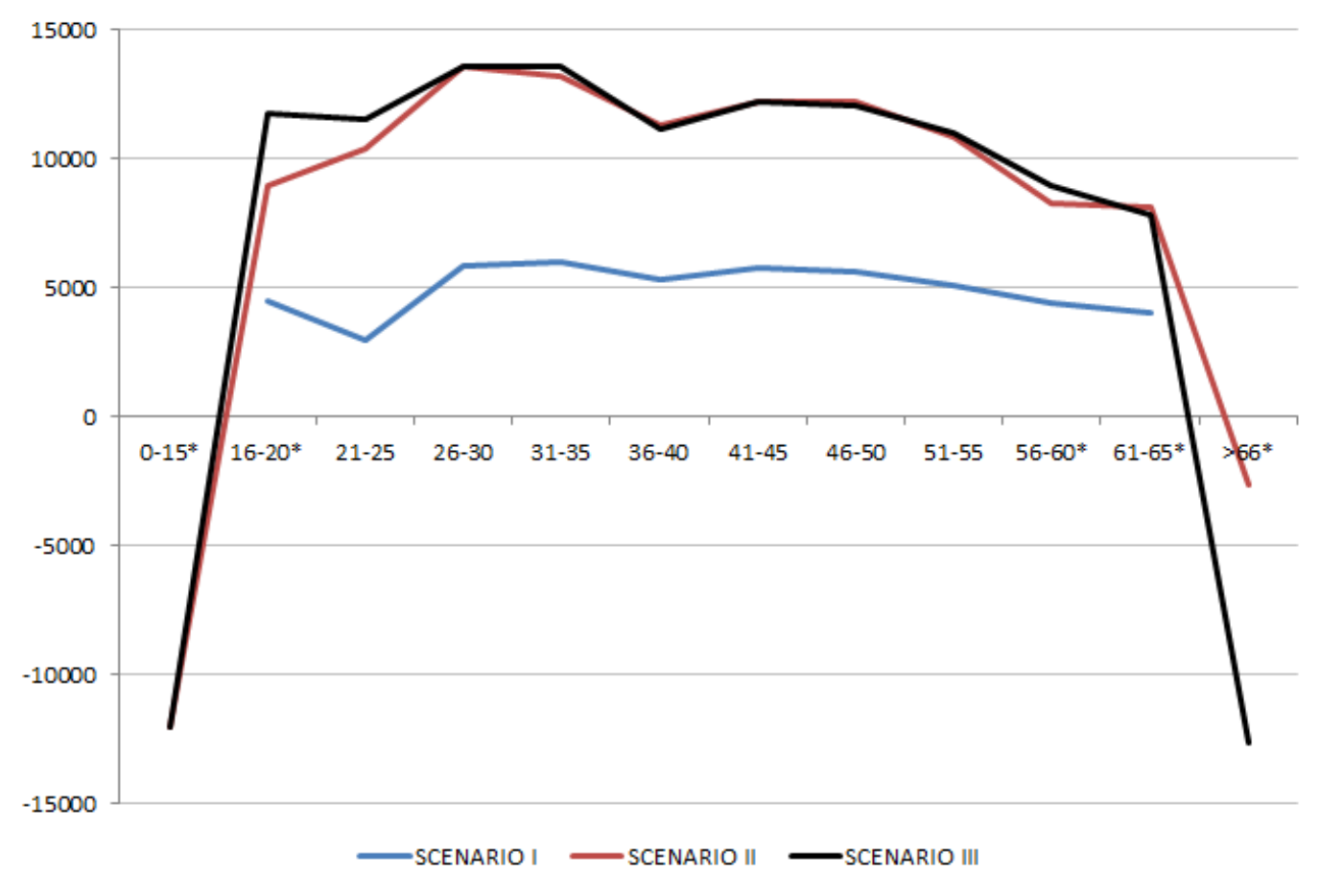

* categories to be treated with caution due to low sample size

Source: Kaczmarczyk 2013.

Figure 4.8 reveals outcomes of three scenarios in a form of net fiscal curve as a function of the age of immigrants. The first scenario is rather conservative in terms of both fiscal sides considered (mostly due to very restrictive assumptions taken). According to this scenario presence of Ukrainian immigrants in Poland brings clearly positive effects for the state budget independent of age. This is the expected outcome while taking into account that the original sample did not include persons aged less than 15 years and more than 66 years and, additionally, an overwhelming majority of Ukrainian migrants constitute persons active on the labor market (working). The second scenario considered includes imputed values for dependents and elderly present in Poland, but also for those who claimed legal work but not necessarily payment of taxes. In this case picture changes remarkably with clearly negative values for persons aged $<15$ and $>66$. In the latter case, however, negative values are relatively low due to low value of pensions assumed. The overall fiscal impact of immigration is unequivocally positive (both due to ratio of people in productive and not productive age as well as due to relatively high positive net revenues in case of persons aged 16-65). Last but not least, scenario III assumes legalization of the Ukrainian immigrants in Poland with important effects on the revenue and expenditure side. However, due to the fact that already large share of Ukrainian immigrants in Poland work (quasi) legally (see previous sections), differences 
between scenario II and III are not impressive and follow mainly from inclusion of dependents / elderly and pension costs for persons staying legally in Poland nonetheless they have clearly negative impact on the aggregated outcome.

Analysis presented by Kaczmarczyk (2013) reveals that Ukrainian immigrants in Poland are unambiguously net fiscal contributors. Such an outcome is a consequence of a few factors. First, generally positive assessment of fiscal position of Ukrainian immigrants in Poland is a result of favorable characteristics of incoming immigrants: immigrants are relatively young and on average well educated. Second, very low share of persons who claim up-take of social benefits results from particular migration strategies in work. Most of Ukrainian immigrants in Poland are to be described in terms of temporary labor migrants. This feature, however, to a large extent is a function of modes of labor market incorporation (as well as demand on foreign labor) and structural characteristics of the Polish welfare state.

\section{Prospects for future inflow from EAPs}

From previous sections it follows that employability of foreigners in Poland is definitely of seasonal nature. This follows from introduction of very liberal legislation as concerns provision of seasonal jobs to citizens of five European states. In practice, however, the demand for seasonal foreign workers is satisfied by Ukrainian nationals. In the post-2009 period the number of work permits issued for employment in excess of one year has grown too, but this growth has been definitely lower than for seasonal employment.

Owing to a very limited scope of foreigners' employment in Poland, any forecast of the scale of their future inflow is an extremely difficult task. Two such forecasts have been attempted in Poland to date: the first one in the frames of a research performed by the Institute of Social Policy (Duszczyk and Szylko-Skoczny 2010) and the other by the Centre of Migration Research (Górny et al. 2010) ${ }^{31}$.

\subsection{The forecast of the Institute of Social Policy}

The first forecast concerned the expected demand for Polish workers. The starting point for the development thereof was a forecast of basic macroeconomic indices (the Gross National Product, employability index, etc.) for the period 2010 - 2020 (at quarterly rate). Owing to the principles adopted in the field of Polish migration (they provide for easy employability of seasonal workers and accessibility of work permits) it can be assumed that the demand from employers for foreign workers is going to be fully satisfied.

The forecast was developed under three scenarios: optimistic, neutral and pessimistic. Under all aforementioned scenarios, the demand for foreign workers is to rise, thus stimulating immigrants' inflow. Simultaneously, depending on the scenario chosen, in 2020 the size of immigration to Poland will be 30-80\% greater than in 2009, with the scale of the fulfilled demand for foreign labor force depending on the economic situation in Poland. The percentage growth may seem significant,

\footnotetext{
${ }^{31}$ Due to the fact that Ukrainian immigrants constitute the single most important immigrant group in Poland both
} attempts can be treated as relevant to the subject of presented study, i.e. immigration from EPCs. 
particularly under the optimistic scenario, but it needs to be pointed out that once translated into absolute numbers the growth would not exceed 10-35 thousand people in permanent employment. In the case of seasonal employment, any potential rise or decline in the demand for seasonal workers will follow from impossible to predict factors, such as e.g. weather conditions affecting vegetable and fruit yields. Simultaneously the existing observations of the trends regarding seasonal employment demonstrate that the scale of such employment will be in the range of 100-200 thousand people annually.

The sectoral forecast demonstrated that both in mid- and long-term perspective, employability of foreigners will focus on agricultural and construction sectors. At the same time there will be regular growth in the employability of foreigners in services sector, in response to the rising demand, which for many reasons cannot be satisfied by domestic workers. The demand forecast has demonstrated that while in 2010 approx. 31\% of foreigners employed in Poland worked in services sector, by 2020 this percentage is going to reach the level of almost $40 \%$. Simultaneously the share of third country nationals employed in agriculture is going to drop from 68 to $60 \%$. Nevertheless agriculture will remain the main sector for foreigners' employment in Poland. However this employment will be largely of strictly seasonal nature.

The projection also demonstrated that in the period 2009-2020 the occupational structure of foreigners working in Poland is going to transform. Firstly, the relative share of poorly qualified construction workers will decline. Secondly, the percentage will grow of foreigners employed at low and medium level positions in services sectors: drivers and machinery operators, salespersons and people providing personal services, office workers and people employed in households. In some of those groups one may expect demand growths of $12-15 \%$ annually, which shall be deemed a quite high value, although it most likely results from a rise of general significance of those groups than from genuine growth of demand for foreigners in those occupations.

\subsection{The forecast of the Centre of Migration Research}

The forecast was developed on the basis of declarations made by employers as regards potential and fulfilled demand for foreign workers. Surveys demonstrated that willingness to hire foreign workers is extremely low in Poland. Mere $5 \%$ of employers declared they would choose a foreigner from among candidates for a job. At the same time survey results unambiguously suggest that such willingness would increase if shortage of Polish workers aggravates, as a result of either demographic change or outflow of Poles abroad. So the grounds to forecast increased employability of foreigners follow from declarations of employers, i.e. a potential demand, which will be fulfilled only under a specified economic situation. A large demand for foreign workers and increased number of decisions to employ them would only take place under good business outlook and shortage of Polish workers in the marketplace. However probability of such scenario in the time perspective of the forthcoming years shall be deemed as very unlikely. 
Additionally, study completed by the CMR in 2010 (Górny et al. 2010) included outcomes of a DELPHI research aimed to assess the scale and structure of future inflow of immigrants to Poland. Majority of experts who were invited to participate in the survey have stated that an increased inflow of labor migrants will occur in the next years. Expected increase was linked to increasing demand for foreign labor connected to massive investments in the infrastructure (related to the 2012 UEFA Cup as well as inflow of EU funds). According to experts main factors which were supposed to enhance future inflows from the EAPs include: spatial proximity, neighborhood and cultural proximity, strong migrant networks and economic factors reflecting the attractiveness of Poland as a destination country. The same factor, however, was presented as potential immigration barrier - in fact, Poland is perceived rather as an (un)attractive country as compared to the Western European countries.

\subsection{Summary}

In recapitulation, the forecasts concerning demand for foreign workers performed in Poland have demonstrated that in the forthcoming years we may be dealing with increased scale of foreigners' participation in the Polish labor market. Additionally, most of the future flows are expected to originate from EAPs - according to DELPHI experts, the most intense inflows are to be expected from Ukraine and Belarus, followed by China, medium-intense inflows are expected from other former USSR republics, while low-intensity inflows are expected from EU countries, India, Pakistan, Bangladesh and Turkey (Górny et al. 2010). At the same time, demand for foreign labor will largely depend on the business outlook and the labor market situation. One may expect significant fluctuations as regards seasonal employment, mainly of the Ukrainian nationals employed in agriculture and construction sector, and a slow growth of permanent employment, to be fulfilled chiefly in services sector. The scale of legal, permanent (in excess of one year) employment by 2020 is going to rise by approx. 30,000 people under the optimistic scenario, or by approx. 10,000 people under the pessimistic scenario.

\section{Conclusions}

In this study we aimed at two goals. The first one was to put together all available data and pieces of other types of information in order to present a broad and coherent picture of immigration from the Eastern Partnership countries. The picture is full to the extent determined by availability of data. To our knowledge there is no relevant piece of information omitted in the paper. The second goal was a set of partial analysis of economic impacts related to immigration from EAPs to Poland, again, conditional on the data availability.

While analyzing recent trends in international migration it is important to consider its developments in longer term. During decades of communist regime the country was almost closed. Poles started sizable emigration in the 1980s. Increasing number of immigrants appeared in the late 1990s and become larger - still low at European 
standards - after 2004 when Poland joined the EU. Today Poland is a country of both large scale emigration and limited but observable immigration, which generates various effects in the labour market and in the broad area of social life. That former situation strongly influenced public perception of immigration but did not contribute yet to sufficient development of an institutional framework needed for managing both flows, namely emigrants and immigrants. The institutional framework is being developed only now, with particular emphasis on social and economic integration of foreigners.

The study presents complexity of the situation and difficulties faced in the process of both on-going managing the flows of migrants and developing the institutional framework for managing that flows. For many reasons such as economic, cultural, political and probably others, the Eastern Partnership programme matters for Poland and also for the entire EU. Development of the institutional framework for managing the immigrant flows is one of the tasks that should be strongly supported in various ways. That is particularly needed in countries like Poland that bordering to largest country covered by the programme, namely Ukraine, is directly exposed to challenges stemming from the programme.

Available data suggests that in many cases Poland is not a final destination for immigrants from the programme countries. However, even in such case the key factor for immigration to Poland are income disparities between the EAPs and Poland. Further migration within the EU is driven by the same factor, namely income disparity between Poland (in general the new member states) and the old member states. The income disparities driven migrations are the most typical in general so the case we analyse do not deviate from common patterns. It has, however, specific features.

In this study we present and analyse the current stage of institutional development and to an extent also efficiency of various arrangements related to immigration (work permits, simplified employment procedure). We also point out their deficiencies and possible ways of further development. We analyse the Eastern Partnership programme in a broad context going beyond just institutions to manage immigration flows. That involves also cultural and historical context that is not directly discussed thou it is taken into account in the background of the paper.

The largest country covered by the programme is Ukraine. Our study also clearly shows the vast majority of issues related to the programme is related to Ukrainian citizens. So it makes a lot of sense to see outcomes of the programme in relation to specific Polish-Ukrainian relations. They have a long history full of good but also dramatic events such as living in the same state on one hand and civil wars involving both nations on opposite sides on the other. Consequently, countries and their inhabitants are close to each other in many senses. There is a number of factors going beyond administrative issues that affect immigration from Ukraine. Actually, the same factors matter with respect to Belarus participating in the programme in a lesser degree. Among them: 
$\checkmark$ Relatively little language barrier;

$\checkmark$ Relatively little cultural barrier;

$\checkmark$ Short distance from home (in many cases just over the border);

$\checkmark$ Similarities of the post second world war history that created similar background of thinking of a couple of generations of Ukrainians and Poles.

There are also other factors applying not only to Ukraine and Belarus but also to the rest of countries covered with the programme:

$\checkmark$ Large agriculture and construction sectors in Poland - typically offering jobs that can absorb immigrant workers (and recently struggling with labor shortages);

$\checkmark$ Relatively strong welfare growth in Poland, especially in big cities, leading to growing demand for various household and care services;

$\checkmark$ Relatively large labor market with clear signs of labor market segmentation;

$\checkmark$ Relatively low unemployment rate (for a number of years below or around the EU average rate);

$\checkmark$ More room for the immigrant workers since the large emigration of Polish workers who flowed out to other EU countries.

Many of the factors quoted above contribute to seasonal pattern of immigration to Poland. Due to legal as well as economic factors, it is relatively easy to come, work for some time and come back to a home country. Immigration to Poland does not mean a substantial investment. Thus, since early 1990s we observe the process of strengthening of the temporary migration pattern from the EAPs. Our study clearly confirms the seasonal pattern of the immigration to Poland. Moreover, in many cases this kind of mobility may transform itself in the long term coping strategy.

In the light of the analysis presented in this paper keeping the door open for immigrants creates some problems, both ones typically faced by receiving countries as well as specific ones stemming from not yet fully developed institutional infrastructure for managing the flow of immigrants as it is the case in Poland. On the other hand, the immigrants contribute to prosperity of Poland and fill in employment gaps that exist due to the emigration of Poles. That situation is expected to stay unchanged in the years to come. Moreover, migration framed within the programme may contribute to building better neighbourhood relations including possible future accession process of some of the countries covered with the programme.

In late November 2012 a draft new act on foreigners was made public (recently in the consultation phase). It indicates key principles for the legal infrastructure of migration policies in Poland. An analysis of this document suggests that Poland's authorities will maintain the existing approach to labor immigration, which means 
priority given to temporary stays. Preferences will also be kept for five East European countries (Ukraine, Russia, Belarus, Moldova and Georgia) as regards facilities for their citizens to take temporary employment without the obligation to obtain a work permit. This means Poland's institutions are to be designed to contribute to beneficial economic outcomes expected from hiring foreigners in such sectors as agriculture, construction and household services. At the same time, introduction of new regulations related to the situation of foreigners undertaking economic activities in Poland is planned. The most important of them provides for the possibility for foreigners to stay in Poland (for maximum of 30 days) despite having lost a job. They will be given the right to seek and start a new job.

The analysis of the rationale for the draft law indicates that currently no other scenarios concerning opening or closing of Polish labor market for foreigners are considered. Such approach seems fully justified in the current situation of Poland. The existing experiences regarding temporary employment of foreigners demonstrate that restriction of labor immigration, particularly from Ukraine, would adversely influence Polish labor market, particularly in the sectors listed above. Reduction of the inflow of foreigners into the agricultural sector would result in difficulties in securing adequate numbers of employees required to harvest the crops, which could have adverse impact on prices of certain agricultural products. It is worth noting that low prices - at least as compared to most other EU member states - in Poland result, among others, from employment of foreigners. In the case of construction sector this impact would be probably less significant mainly due to the fact that many infrastructural investment projects co-financed from EU funding have ended and consequently the demand for employees in the construction sector has decreased. The demand may rise again when new investments co-financed from the 2014-2020 EU budget are deployed. Restriction on the possibility to hire household help may push some Poles, mainly women, to give up their jobs and take on duties presently performed by foreigners. This concerns mainly long-term care for dependent persons. The necessity to ensure assistance in private homes stems from underdeveloped institutional care services.

Given the current situation in the labor market and the scale and structure of immigration to Poland as presented in this paper, we do not expect a fundamental change of the picture of immigration even under a scenario of full liberalisation of the access of EAPs citizens to Polish labor market. Under current regulations, the access to temporary employment is practically free (up to 6 months) for the EAPs citizens. The overall situation may change if the constraint on the period of temporary employment (no work permit required) was relaxed. It is likely a significant number of foreigners, who presently leave Poland after maximum of six months of employment, would stay and work for a longer period. However, such relaxation of regulations is not currently considered. In general there is no sign of a significant change of the currently applied policies in the area of immigration. The most likely scenario is a current status quo one as regards admittance of the citizens of EAPs states to Polish labor market. 
Last but not least, solving inevitable problems stemming from the growing flow of immigrants (based on historical Polish standards they can be perceived as almost large) should clearly focus on development of institutions responsible for social integration and contributing to prevent prejudice and other problems related to the perception of immigrants. For Poland an immigrant friendly labor and social infrastructure - if well designed and efficiently working - may be an additional factor contributing to welfare and prosperity of the country. 


\section{References}

Anioł W. (1995). Elementy kształtowania polskiej polityki migracyjnej (The elements of Polish migration policy formation), The Faculty of J ournalism and Political Sciences of the Warsaw University, Warsaw.

Barrett, A. and B. Maitre (2011). Immigrant Welfare Receipt across Europe. IZA Discussion Papers No. 5515, Institute for the Study of Labor (IZA).

CSO (2012). Wyniki Narodowego Spisu Powszechnego Ludności i Mieszkań 2011, Warsaw: CSO.

Dustmann, Ch., Frattini, T. and C. (2010). Assessing the Fiscal Costs and Benefits of A8 Migration to the UK. Fiscal Studies 31(1): 1-41.

Duszczyk M. and M. Szylko-Skoczny (2010). Raport końcowy z przygotowania optymalnego dla Polski modelu polskiej polityki imigracyjnej [The final report on the development of Polish immigration policy optimised for Poland], Warsaw: The Institute of Social Policy of the Warsaw University for the Human Resources Development Centre.

Fedoryshyn I. (2011). Labor Immigration and Contemporary Welfare States. The Case of Ukrainian Immigrants in Poland, unpublished manuscript, Warsaw: Faculty of Economics.

Fihel A. (ed.) (2012). Recent Trends in International Migration in Poland. The 2011 SOPEMI Report, CMR Working Papers 52/110.

Frelak J. (2005). Praca Ukraińców w Polsce - rekomendacje dla polityki migracyjnej (The work carried out by Ukrainians in Poland - recommendations for migration policy), Analizy i Opinie, 38, Warsaw: Instytut Spraw Publicznych.

Friedberg, R.M. and Hunt, J . (1995), The Impact of Immigrants on Host Country Wages, Employment and Growth, J ournal of Economic Perspectives- Volume 9, Number 2-Spring 1995-Pages 23-44

Górny A., Grabowska-Lusińska I., Lesińska M. and M.Okólski (eds) (2010), Immigration to Poland: policy, labor market, integration, Warsaw: Scholar.

Iglicka K. (2000). Ethnic division on emerging foreign labor markets in Poland during the transition period, Europe-Asia Studies 52 (7).

J anicka A. and P. Kaczmarczyk (2010). Economic consequences of the inflow and the sustainability of migration, in: Górny A., Grabowska-Lusińska I., Lesińska M. and M. Okólski (eds) Immigration to Poland: policy, labor market, integration, Warsaw: Scholar.

Kaczmarczyk P. (2013). Burden or relief? Fiscal impacts of recent Ukrainian immigrants in Poland (unpublished manuscript).

Kaczmarczyk P. (ed.) (2011). Mobility and Migration at the Time of Transition: Methodological Challenges, Warsaw: Scholar [in Polish].

Kaczmarczyk P. and M. Okólski (eds) (2008). Polityka migracyjna jako instrument promocji zatrudnienia i ograniczania bezrobocia, Warsaw: CMR [In Polish]. 
Karpiński, A., Paradysz, S. and Penconek, B. (1999), Szacunek zapotrzebowania na główne grupy zawodów do roku 2010, Rządowe Centrum Studiów Strategicznych, Warszawa

Kucharski, L., Kubiak, P. and Roszkowska (2010). Ocena prac badawczych w zakresie prognozowania zatrudnienia według zawodów w Polsce, Warszawa.

Kus J . (2004). Undeclared Labor in the Construction Industry. Country report - Poland. European Institute for Construction Labor Research, available at : http:// www.clrnews.org/ CLRStudies/ Poland\%2003-OK. pdf

Lucchino, P., Bondibene, C.R. and Portes, J . (2012), Examining the relationship between immigration and unemployment using National Insurance Number registration data, NIESR Discussion Paper No. 386.

MLSP (2011), Zawody deficytowe i nadwyżkowe w I półroczu 2011, Warsaw: Ministry of Labour and Social Policy [http:// www.mpips.gov.pl/analizy-i-raporty/ raportysprawozdania/rynek-pracy/ zawody-deficytowe-i-nadwyzkowe/]

OECD (2013). The fiscal impact of immigration in OECD countries. In: OECD. International Migration Outlook. Paris: OECD.

\section{Legal acts:}

Chapter 6 of the Act on employment of 29th December 1989 (the J ournal of Laws of 1989 No. 75 items 445 and 446).

The Act on employment promotion and labour market institutions of 20th April 2004 (the J ournal of Laws 2004 No. 99 item 1001).

The Amendment to the Act on employment promotion and labour market institutions of 19th December 2008 (the J ournal of Laws 2009 No. 6 item 33).

The Regulation of the Minister of Labour and Social Policy on performance of work by foreigners without a necessity to obtain a work permit (the J ournal of Laws 2006 No. 156, item 1116).

The Regulation of the Minister of Labour and Social Policy on the cases in which the assignment of work for a foreigner in the territory of the Republic of Poland shall be permitted without obtaining a work permit of 20th J uly 2011 (J ournal of Laws No. 155, item. 919). 